\title{
3 Population, Migration, Ageing and Health: A Survey
}

\author{
Christian Dustmann, Giovanni Facchini \\ and Cora Signorotto
}

\begin{abstract}
We review the literature on recent demographic changes in Europe, focusing on two of the main challenges brought about by an ageing population: severe labour shortages in many sectors of the economy and growing pressures on both health and welfare systems. We discuss how and to what extent migration can contribute to addressing these challenges both in a short and a long-term perspective. Finally, we identify several areas in which more research is needed to help devise more effective policies to cope with a greying society.
\end{abstract}

\subsection{Introduction}

As European countries experience rapidly ageing populations, two major challenges have emerged for policy-makers. First, the decline in the size of the domestic labour force implies severe shortages in the availability of key skills needed in several sectors of the economy. ${ }^{1}$ Possible consequences are reduced productivity growth and decline in global competitiveness. Second, the increase in life expectancy will typically imply longer periods spent in retirement, generating pressures on the sustainability of existing pension systems, as well as new needs to provide care for a growing elderly population.

Immigration is often referred to as a possible response to address both of these challenges. Young foreign workers can fill some of the short-term skill shortages that have emerged and contribute in the medium and long run to reversing the trend towards population stagnation. At the same time, cultural differences and the common perception that foreigners might be a threat for the domestic population, in conjunction with the large migrations required to counter demographic developments in many European countries, suggest that migration can only be part of a broader mix of interventions.

The goal of this survey is to provide a systematic overview of the literature that has analysed the interplay between population dynamics, ageing, health and migration, aimed at offering policy-makers a sound understanding of the state of the art in this important research area. At the same time, we will identify 
key issues where more research is needed both to foster our knowledge, as well as to provide guidance for effective policy interventions. The review is carried out from the perspective of the economics literature, but given the complexity of the question we also refer to relevant studies carried out by demographers and sociologists.

Following an initial description of the main stylized facts on population ageing, migration and health in Section 3.2, the survey focuses on current demographic developments and fertility trends among the migrant and native populations in destination countries (Section 3.3) and on the length of the migration spell (Section 3.4). We then review the main findings in the literature on the fiscal effects of migration in European countries and the US (Section 3.5) and describe the role that migration can play in addressing skill and labour shortages (Section 3.6). Section 3.7 analyses the health care sector, focusing on shortages of health care workers in European countries and the international migration of health professionals. Finally, we present the main findings from the very recent literature on amenity-driven migration of retirees from Northern European countries towards Mediterranean coastal regions (Section 3.8). Section 3.9 summarizes our main conclusions and policy implications.

\subsection{Main Stylized Facts}

Europe's population is ageing rapidly ${ }^{2}$ and, as shown in Figure 3.1, the most recent forecasts suggest that the phenomenon is likely to become more severe over the next 45 years (see European Commission, 2014a). By 2060, less than 57 per cent of the population is expected to belong to the economically active group.

There are two main reasons why a population ages. First, a decline in overall fertility rates. Second, an increase in life expectancy. Considering the 28 current members of the EU, average total fertility rates were on a steady downward path over the period from 1960 to 2005. While in 1960 the average European woman was expected to give birth to 2.67 children, this number dropped to only 1.49 children by 2005 . There was a slight improvement in total fertility over the last decade, with fertility reaching 1.56 by 2012 . This basic trend conceals important differences across countries, however. For instance, while fertility rates in Ireland have been consistently higher than in the rest of the EU, countries like Portugal or Spain had substantially higher fertility rates than the EU average in the 1960s, 1970s and even 1980s, but then saw them drop below the EU average starting in 1990. Other countries like France have been able, through a series of targeted policies, to maintain fertility rates close to the replacement rate of 2.1 children per woman (see Figure 3.2). The most recent forecasts indicate that we should expect a slight improvement over the next 45 years, with total fertility 


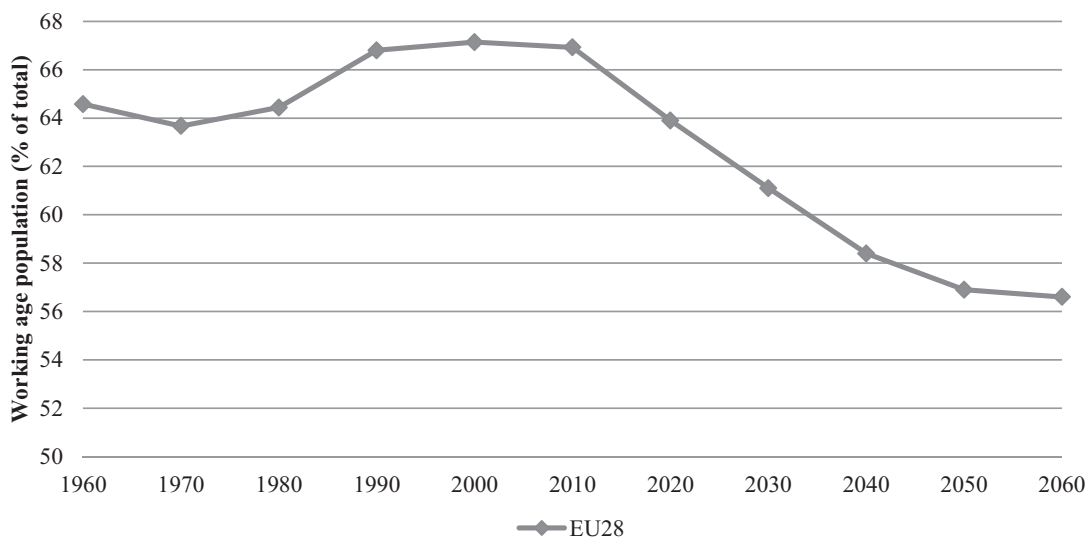

Figure 3.1 Working age population in the EU28: Past trends and projections (European Commission, 2014a, p. 409). Figures always refer to the same group of countries.

rates reaching 1.76 children by 2060 , a figure that is still substantially short of the natural replacement rate (see European Commission, 2014a).

Over the same period, life expectancy has increased dramatically. The European Commission Ageing Report (2014a) shows that the average man born in an EU country in 1960 is expected to live 66.9 years, whereas the average woman lives 72.3 years. By 2010 these figures had increased dramatically to 75.6 years for men and 82 years for women, that is, by a staggering 13 per cent (see Figure 3.3), and life expectancy is forecast to continue to rise. By 2060

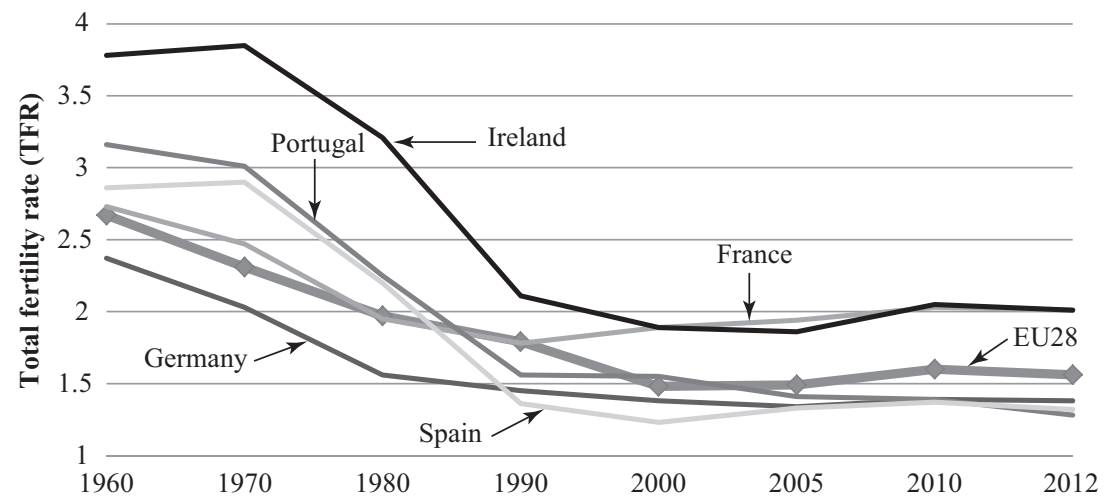

Figure 3.2 Past trends in total fertility rates (TFR), 1960-2012: Selected EU countries (European Commission, 2014a, p. 9). 


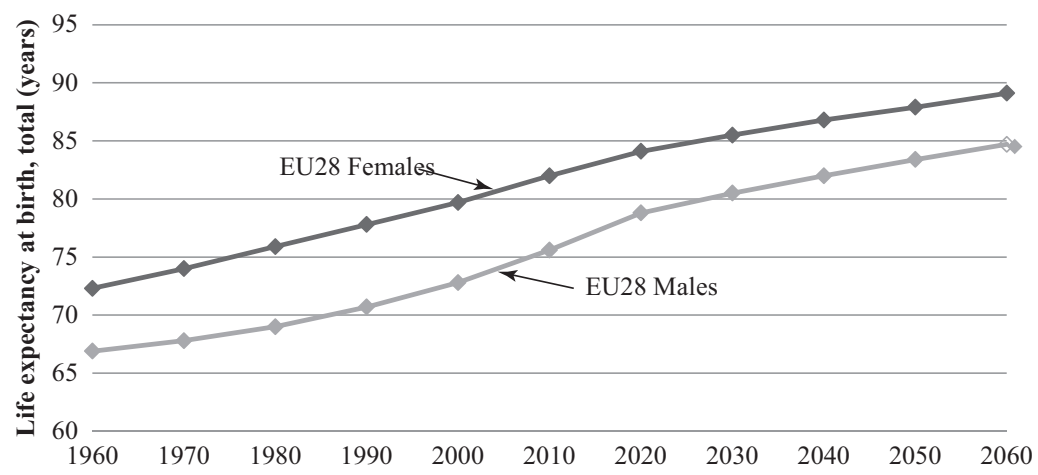

Figure 3.3 Life expectancy at birth in the EU28: Past trends and projections (European Commission, 2014a, pp. 12-13). Figures always refer to the same group of countries, with the exception of 1960, when no data are available for Cyprus and Romania, and 1970, when no data are available for Cyprus.

it is expected to reach 84.7 years for males and 89.1 years for females (see European Commission, 2014a).

Population ageing will generate growing pressures on welfare states, adding strains to existing pension systems, which might no longer be able to guarantee adequate living standards in old age. Similarly, health systems are expected to require more resources and to adapt to an increased demand for long-term care (LTC) for a growing elderly population.

In fact, as pointed out by the European Commission (2015), the expected gross replacement rate of public pensions has declined in all EU countries. Furthermore, the burden of health and long-term care (LTC) on public finances is expected to increase. Figure 3.4 reports forecasts for the EU Health and LTC expenditures as a percentage of GDP for the next 45 years. Health expenditures will reach 7.9 per cent of GDP by 2050 and level off the following decade, while spendings on LTC services are predicted to increase by 1.1 percentage points by 2060 (European Commission, 2015).

In principle, immigration can help offset these trends by increasing both the size of the working age population and the total fertility rate. Considering the EU, a positive net inflow ${ }^{3}$ has been consistently observed since the second half of the 1980s (see European Commission, 2014a). In particular, new arrivals peaked in 2003, averaging well over a million per year. Following a sharp drop during the global economic crisis, net migration flows picked up once again after 2011 and reached pre-crisis levels by 2013 - the last year for which data are available (see Figure $3.5^{4}$ ). 

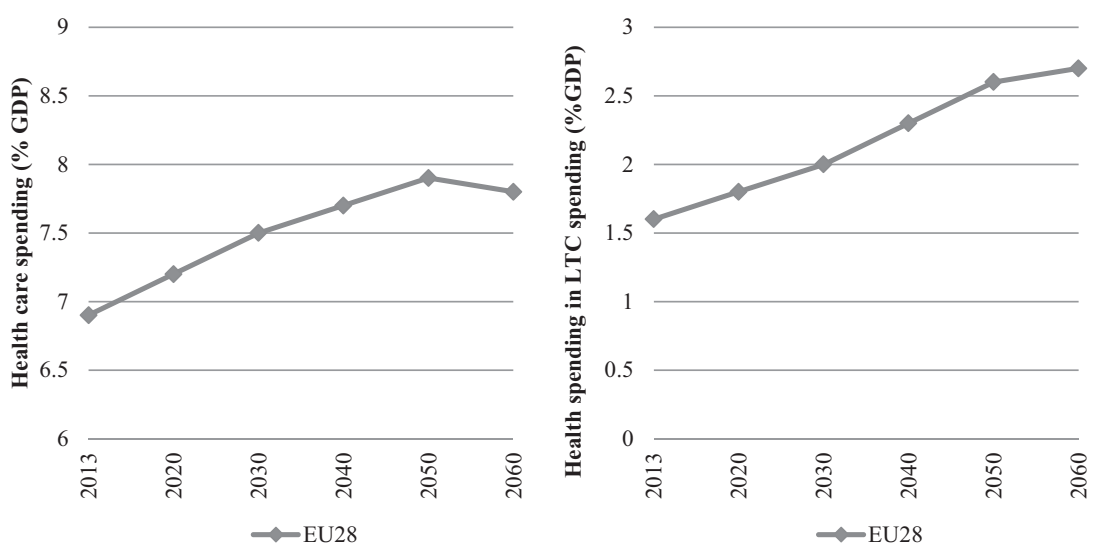

Figure 3.4 Projections of health care and long-term care spending as percentage of GDP for EU28 countries (European Commission, 2015, pp. 265, 271).

According to the most recent projections, ${ }^{5}$ between 2013 and 2060 cumulated net inflows to the EU are expected to reach 55 million. The main destination countries will be Italy, the United Kingdom, Germany, and Spain, with a forecasted cumulated net inflow of 15.5 million, 9.2 million, 7 million and 6.5 million migrants respectively (see European Commission, 2014a).

Whether migrants help rejuvenate Western countries ultimately depends on their age structure and fertility behaviour. In the next section, we will review the main differences in fertility patterns among the migrant and native populations, and discuss the extent immigration represents a viable solution to the host countries' ageing workforce.

\subsection{Migration and Demographic Developments}

Migrants are typically younger than natives when they arrive, and in the short run they contribute to rejuvenating the host country's labour supply. In the medium to long run, migrants will age as well, and new immigration will be required to counteract population ageing. One key factor determining to what extent the host country's age structure is affected by immigration in the medium or long term is the relative fertility of the immigrant compared to the native population.

To understand the importance of immigration in shaping future population dynamics, Table 3.1 (taken from Sobotka, 2008) displays the share of total births accounted for by immigrant women in eleven European countries. Almost all countries in the table have experienced a steady increase in the share of births to immigrant women since the mid-1990s. Southern European 


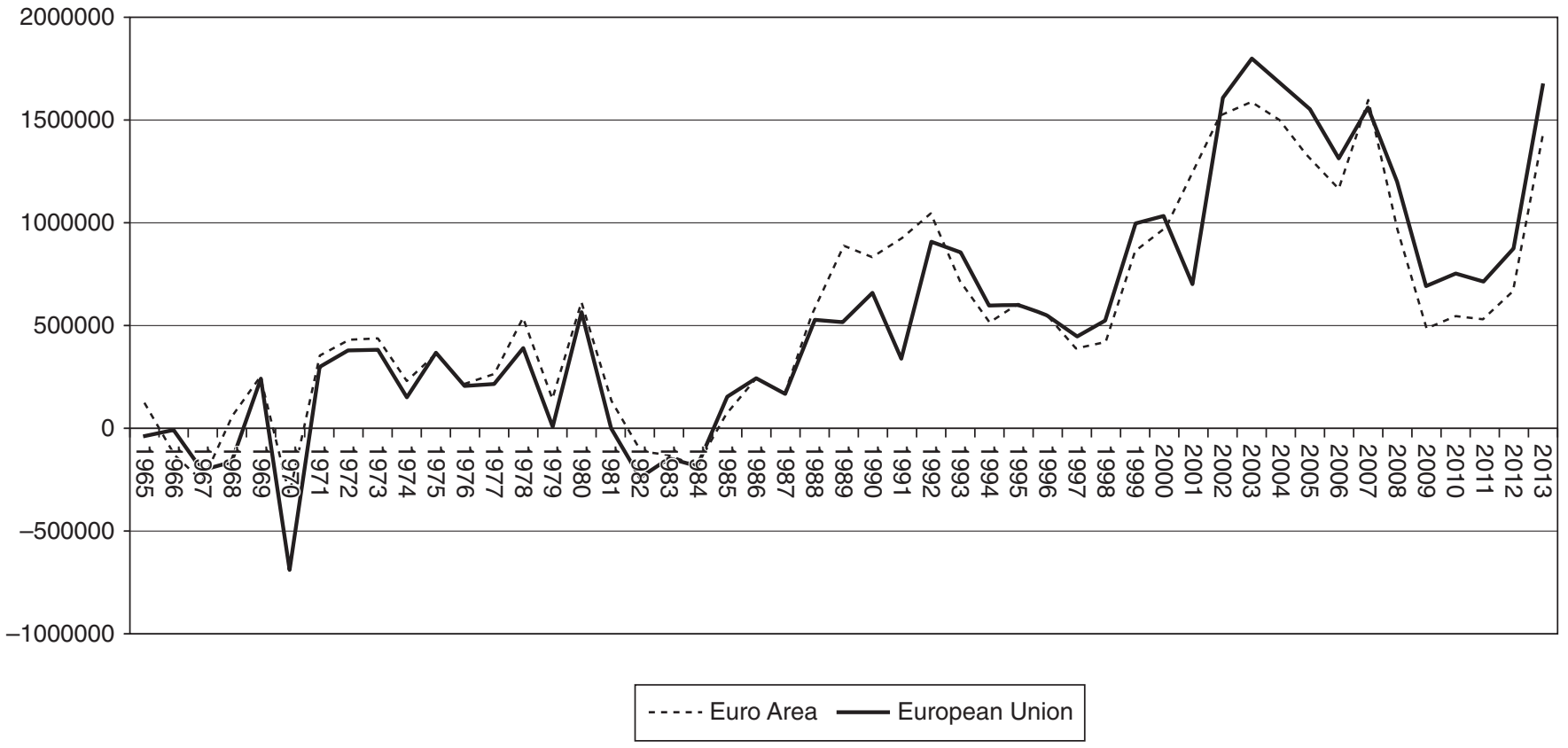

Figure 3.5 Net migration flows, 1965-2013 (European Commission, 2014a, p. 14). Figures always refer to the same group of countries. 
Table 3.1 Births to immigrant parents (Sobotka, 2008, p. 230)

\begin{tabular}{|c|c|c|c|c|c|}
\hline Country $^{a}$ & Period & $\begin{array}{l}\text { Births to } \\
\text { immigrant } \\
\text { women }(\%)\end{array}$ & $\begin{array}{l}\text { Births to } \\
\text { immigrant } \\
\text { women, 1st + } \\
\text { 2nd gen. (\%) }\end{array}$ & $\begin{array}{l}\text { Births to } \\
\text { mothers } \\
\text { with foreign } \\
\text { nationality }(\%)\end{array}$ & $\begin{array}{l}\text { At least } \\
\text { one parent } \\
\text { foreign } \\
\text { national }(\%)\end{array}$ \\
\hline \multirow[t]{2}{*}{ Austria } & 2000 & & & 13.5 & \\
\hline & 2005 & & & 11.7 & \\
\hline $\begin{array}{l}\text { Belgium } \\
\quad \text { (Flanders) }\end{array}$ & 2003-04 & 16.8 & & 12.4 & \\
\hline Denmark & 1999-03 & 13.5 & & 11.1 & \\
\hline \multirow{5}{*}{$\begin{array}{l}\text { England and } \\
\text { Wales }\end{array}$} & 1980 & 13.3 & & & \\
\hline & & & & & \\
\hline & 1995 & 12.6 & & & \\
\hline & 2005 & 20.8 & & & \\
\hline & 2006 & 21.9 & & & \\
\hline \multirow[t]{3}{*}{ France } & 1991-98 & 12.4 & & & \\
\hline & 1998 & & 21 & & 14.5 \\
\hline & 2004 & 15 & & 12.4 & 18.2 \\
\hline \multirow[t]{4}{*}{ Germany } & 1980 & & & 15 & \\
\hline & 1985 & & & 11.2 & \\
\hline & 1995 & & & 16.2 & \\
\hline & 2004 & & & 17.6 & \\
\hline \multirow[t]{3}{*}{ Italy } & 1999 & & & 5.4 & \\
\hline & 2004 & & & 11.3 & \\
\hline & 2005 & & & 12.2 & \\
\hline \multirow[t]{2}{*}{ The Netherlands } & 1996 & 15.5 & 21 & & \\
\hline & 2005 & 17.8 & 25.5 & & \\
\hline \multirow[t]{4}{*}{ Spain } & 1996 & & & 3.3 & 4.5 \\
\hline & 2000 & & & 6.2 & 7.9 \\
\hline & 2004 & & & 13.7 & 16.9 \\
\hline & 2006 & & & 16.5 & \\
\hline Sweden & 2005 & 19.5 & & 11.8 & \\
\hline \multirow[t]{3}{*}{ Switzerland } & 1980 & & & 15.3 & \\
\hline & 2000 & & & 22.3 & \\
\hline & 2005 & & & 26.3 & \\
\hline
\end{tabular}

a Notes: Country data sources: Austria: Kytir (2006); Belgium: VAZG (2007); Denmark: Statistics Denmark (2004); England and Wales: ONS (2006), ONS (2007), Schoorl (1995); France: Héran and Pison (2007), Prioux (2005), Toulemon (2004), Tribalat (2005); Germany: Schoorl (1995), Statistisches Bundesamt (2006); Italy: ISTAT (2007); Netherlands: CBS (2006); Spain: INE (2006), INE (2007), Roig Vila and Martín (2007); Sweden: Statistics Sweden (2006); Switzerland: Coleman (2003), SFSO (2006).

countries in particular report a sharp increase in fertility, which is at least partly due to the high immigration inflows they experienced in the 1990s and early 2000s.

Three main mechanisms affecting migrants' fertility behaviour have been studied in detail: selection, disruption and adaptation (for a comprehensive 
overview, see Adserà and Ferrer (2015). In the remainder of this section we will consider each one of them in turn.

\subsubsection{The Selection Hypothesis}

The first hypothesis we consider suggests that immigrant women are a selfselected sample of the country of origin's population in terms of their level of education, potential income, age, etc. This may make them different from women left behind when it comes to fertility and childbearing behaviour.

Kahn (1988) is one of the first systematic analyses of fertility differentials between native and foreign born women, and in particular of the role played by selection into emigration. Using individual level data from the 1980 US Census and aggregate data from origin countries, she performs a simple covariance analysis, highlighting the role of sending-country fertility levels in determining migrants' fertility behaviour. Migrants from high-fertility countries report, on average, higher fertility once in the host country compared to migrants from lower fertility countries. This positive relationship, however, is partly offset by self-selection: when immigrants are positively selected in terms of education, the influence of the high-fertility source-country norms is weaker and their fertility tends to be lower. Kahn also examines the fertility behaviour of child and adult immigrants separately and finds that adult immigrants have higher mean levels of fertility. This is partly explained by the fact that the latter tend to be older and somewhat less educated than child immigrants.

Using data from the 1970 and 1980 US Census and focusing on high fertility sending countries located in the Middle East, Asia, Latin America and the Caribbean, Blau (1992) finds evidence of a broadly similar fertility behaviour between immigrant and native women. In particular, her results indicate that immigrant women observed in 1970 have slightly fewer children than their native counterparts. She explains this finding by the positive selection of immigrants with regard to education, and by the fact that highly educated immigrant women tend to have fewer children than native women with comparable characteristics. Blau also finds indirect evidence of a higher demand for child quality among immigrant than among native women. In a more recent paper, Avitabile et al. (2014) use German data to show that the acquisition of citizenship rights is likely to reinforce migrants' preferences for child quality rather than quantity and reduce immigrants' fertility.

Evidence of migrants' positive selection on education is also reported by Choi (2014). The novelty of her study lies in combining nationally representative datasets from Mexico and the US: the 2002 Mexican Family Life Survey and the 2002 and the 2006-2010 US National Survey of Family Growth. The rich dataset built by the author allows her to identify a disruption in fertility in anticipation of migration, but a resumption of pre-migration fertility patterns 
and partial compensation for the earlier fertility loss after migration. Interestingly, she also finds that fertility levels among Mexican-Americans decrease both within and across generations, as increasingly educated immigrants adopt the fertility patterns of white Americans. Still, the data show that MexicanAmerican fertility has not yet fully converged to that of white Americans.

\subsubsection{The Adaptation Hypothesis}

Even if migrants are a selected group relative to both the source and destination country populations, their behaviour is likely to change once they settle in the new country. Immigrants may adapt and adjust their initially higher fertility rate to that of the native population over time. Research on fertility assimilation processes has addressed the issue following three different approaches: by distinguishing between first and second generation immigrants (Stephen and Bean, 1992, Parrado and Morgan, 2008, Dubuc, 2012), by focusing on foreign born migrants who migrated as children (see e.g., Kahn, 1988, Bleakley and Chin, 2010, Adserà et al., 2012), or by studying the impact and strength of cultural and ethnic 'ties' over time (Fernández and Fogli, 2009, Blau et al., 2013).

The findings in the literature indicate that second generation and child immigrants' fertility behaviour is closer to that of the native population. Country of origin characteristics, like language and cultural heritage, may also contribute to the gap between immigrants and natives, and to the pace of assimilation.

For the US, Parrado and Morgan (2008) assess the fertility assimilation hypothesis for Hispanic and Mexican immigrants. They estimate fertility by computing the average number of children ever born for three immigrant generations of Hispanic and Mexican women born between 1885 and 1964. Their cohort and generational analysis reveals a declining trend in immigrants' fertility, which is consistent with the assimilation hypothesis. Mexican immigrant women are found to have significantly lower fertility levels than nonmigrant Mexican women. Evidence of convergence to the fertility of white women across immigrants' generations is also found.

Using data from the 1970 and 1980 US Census, Stephen and Bean (1992) likewise focus on Mexican women's fertility trends in the US, considering both first and second generation migrants. The authors report evidence consistent with assimilation across generations to non-Spanish-origin white women's fertility patterns: US-born Mexican immigrants have lower fertility rates than the first generation born in Mexico.

Evidence of fertility assimilation emerges also from European studies. Dubuc (2012) analyses fertility rates of second generation immigrants in the UK and compares them to those of their parents and to those of recent immigrants from the same ethnic group. While she finds evidence of fertility differentials by ethnic groups, she uncovers at the same time a convergence towards 
lower UK average fertility levels. The decrease in the fertility gap over time is found to be the result of both a decline in fertility of immigrants originating from high-fertility countries and lower fertility rates of second generation immigrants.

In an interesting paper, Adserà et al. (2012) focus on the fertility behaviour of women who migrated as children to Canada, the UK and France. Focusing on adaptation mechanisms, they perform a Poisson regression analysis to estimate the main determinants of the number of live births per woman. Their results are consistent with the assimilation hypothesis. They also illustrate a considerable heterogeneity in the effect of time spent in the destination country on the fertility of immigrants who are from different origin countries.

The heterogeneity in fertility behaviour driven by differences in migrants' countries of origin has been explained in the literature by the cultural and linguistic characteristics of the sending countries. Bleakley and Chin (2010) investigate the interrelation between English proficiency and social integration of immigrants in the US using microdata from the 2000 Census and exploiting information on immigrants' age at arrival and on whether they were born in an English-speaking country. Interestingly, they find evidence that immigrants who are more fluent in English have fewer children than less fluent immigrants.

Besides language, immigrants' cultural heritage may alter or delay the process of fertility assimilation through the intergenerational transmission of fertility behaviour. Fernández and Fogli (2006) try to disentangle the effects of personal-family related experiences (e.g., the number of a woman's siblings) from those driven by source country heritage. Their findings indicate a positive and significant impact of both family fertility experience and cultural heritage on fertility behaviour of US-born immigrant women. In a related paper, Fernández and Fogli (2009) use data from the 1970 US Census and find a similar effect of the migrants' culture of origin on the fertility behaviour of second generation immigrants.

Blau et al. (2013) extend Fernández and Fogli's analysis and allow the cultural heritage to vary across birth cohorts of second generation immigrants in the US. To this end, they combine information on second generation women immigrants taken from the 1995-2006 March Current Population Survey with parental characteristics constructed using the 1970, 1980, 1990 and 2000 Censuses. The authors are in particular interested in studying the transmission of first-generation immigrants' education, fertility, and labour supply to secondgeneration women labour supply and fertility behaviour. Their rich dataset allows them to separately study the effect of each parent's (mother and father) characteristics. Their results indicate that second-generation women's education, fertility and labour supply are positively affected by the corresponding immigrant generation's characteristics, even within an overall pattern of assimilation. Moreover, fertility and labour supply behaviours appear to be more 
strongly influenced by the fertility and labour supply characteristics of the mother's country of birth, whereas educational attainment is more strongly influenced by the norm prevailing in the father's country of birth.

\subsubsection{The Disruption Hypothesis}

The decision to migrate might affect reproductive behaviour, for instance, because a migrant decides to postpone childbearing after arrival into the new country due to a temporary negative income shock. Migrants may also be forced to postpone childbearing due to separation from the spouse around the time of migration (see Blau, 1992).

Disruption mechanisms can be observed when a decline in fertility occurs right before or right after migration, which may or may not be followed by a catchup. Assessing the disruption hypothesis empirically presents significant challenges as it requires information on pre-migration fertility patterns and because the migrant population is likely to be a nonrandomly selected subgroup (Adserà and Ferrer, 2015). US studies report evidence of migrants interrupting fertility around the time of migration, while results for European countries vary substantially by destination.

In an early study, Kahn (1994) exploits information from the 1980 US Census and the 1986 and 1988 June Current Population Surveys on the actual number of children ever born and the number of children women expect to have in the future. In particular, she runs a synthetic cohort analysis to trace the fertility pattern of a fixed cohort of immigrants in the 1980s and then compares the results with migrants' fertility expectations. The observed increase in the immigrant-native fertility gap in the 1980s is explained as a consequence of a sharp decrease in natives' fertility compared to immigrants' rather than a rise in migrants' fertility. The fertility gap is mainly explained by socio-economic and demographic differences between the migrant and native populations in terms of skills, income and ethnicity. However, the synthetic cohort analysis reveals that part of the fertility differential is driven by a disruption followed by catchup in fertility behaviour. Kahn's analysis of fertility expectations confirms this result: while recent immigrants are found to have had lower than average fertility compared to older immigrants' cohorts and natives, they are also found to compensate for this gap by expecting to have more children in the future. Blau (1992) also finds evidence of disruption in the fertility profiles of US immigrants, and attributes it to demographic factors such as delayed marriages or spouses' temporary separation due to migration, rather than to economic factors such as spouses' temporary income loss. Focusing on Mexican immigrants to the US, Choi (2014) finds evidence of disruption in fertility right before migration. Migrants seem to partially make up for the initial loss 
in fertility once they are in the destination country, but she finds evidence of a long-term effect of the initial shock.

In Europe, Andersson (2004) uses Swedish longitudinal register data and finds evidence of a before-migration disruption in fertility, which is followed by a right-after-migration catchup. Toulemon (2004) and Toulemon et al. (2008) also find evidence of disruption patterns in fertility for immigrants to France. Different results emerge instead in a study carried out by Garssen and Nicolaas (2008) on migrants to the Netherlands. Using information from Dutch municipal population registries for 2005, they find that Turkish and Moroccan women display higher fertility rates than those reported in their country of origin, and argue that migration for family formation reasons might explain this trend. Female migration from Turkey and Morocco, in fact, is mainly motivated by family reunification, given the traditional role of women in these source countries. Similar results are obtained also by Mayer and Riphahn (2000) in their analysis of assimilation and/or disruption patterns in the fertility of immigrants to Germany.

\section{Open Issues}

Data limitations is one of the main difficulties researchers face when studying immigrant fertility. In particular, detailed information on immigrants' lifetime events such as age at migration, complete birth histories (i.e., before and after migration), return migration and the socio-demographic characteristics of their families of origin would allow for a more comprehensive analysis of migrants' demographic trends.

Overall, and despite current limitations in fertility estimates and projections, the evidence we have reviewed suggests that migrants tend to assimilate to the destination country's fertility patterns. Immigrants' younger age and initially higher fertility rates may help rejuvenate the host countries' populations in the short run. However, migrants' assimilation to the host country fertility patterns implies that such rejuvenation will largely have to rely on a continuous inflow of immigrants. Therefore, migration alone is unlikely to compensate for the ageing workforces in European countries.

\subsection{Permanent versus Temporary Migration}

To fully understand the demographic and fiscal impact of immigration on the host countries, we must consider whether migrations are permanent or temporary, and more generally what their durations are. If immigration is predominantly permanent, older migrants will contribute to the ageing of the host country population in the longer run, and to an increase in the demand for health and long-term care services. If, however, most migrations are temporary, immigrants may contribute to rejuvenating the existing workforce and contribute in 
terms of taxes, and will burden the host country to a lesser extent in old age. Also, as immigrants are heterogeneous, it is important to understand whether those who leave the host country are systematically different from those who remain in terms of skill level and labour market outcomes. Temporary migrations can take different forms. They may be return migrations, where migrants return permanently to their countries of origin after a period in the host country; they may be circulatory migrations, with migrants migrating back and forth between origin- and destination country; or they may be transient migrations, where individuals move from country to country before reaching a final destination (see e.g., Nekby, 2006; see Dustmann and Görlach, 2016 for a discussion).

Nonpermanent migration plays an important role in many destination countries. Figure 3.6 - taken from Dustmann and Görlach $(2016)^{6}$ - plots the estimated share of immigrants who leave the host country against the number of years since migration. The figure illustrates that European countries display significantly higher outmigration rates compared to the more traditional destination countries. In particular, almost 50 per cent of immigrants to Europe have already left their first destination country ten years after arrival, while this is true for only about 20 per cent of immigrants to Anglo-America, Australia and New Zealand. These figures are in line with other studies that quantify the extent of return migration for specific countries. For instance, Dustmann and Weiss (2007) report that in the UK, more than 40 per cent of each arrival cohort has left the country after about 5 years.

Starting in the late 1980s, scholars began to investigate why migrants outmigrate from destination countries, and who the return migrants are, addressing the selectivity in the return migration decision and its effects on the host economy (see early papers by Dustmann, 1995, 1997, 2003, Borjas and Bratsberg, 1996 and Dustmann et al., 2011). ${ }^{7}$

\subsubsection{Why Do Migrants Return?}

In simple neoclassical models the migration decision only depends on differences in relative wage levels net of relocation costs, and on expectations of higher earnings in the country of destination. Within this framework, the individual migrates assuming to remain permanently in the destination country. Return migration in this setting is the result of mistaken expectations, meaning that the migrant assessed the benefits of migration inaccurately. More recent contributions, however, have introduced models of endogenous return migration decisions. In a recent paper, Dustmann and Görlach (2016) discuss different factors that may contribute to a migrant's return decision, such as a higher preference for consumption in the country of origin than in the host country, a lower price level in the migrant's origin country compared to the host country, and the possibility for the migrant to accumulate human capital faster in the 


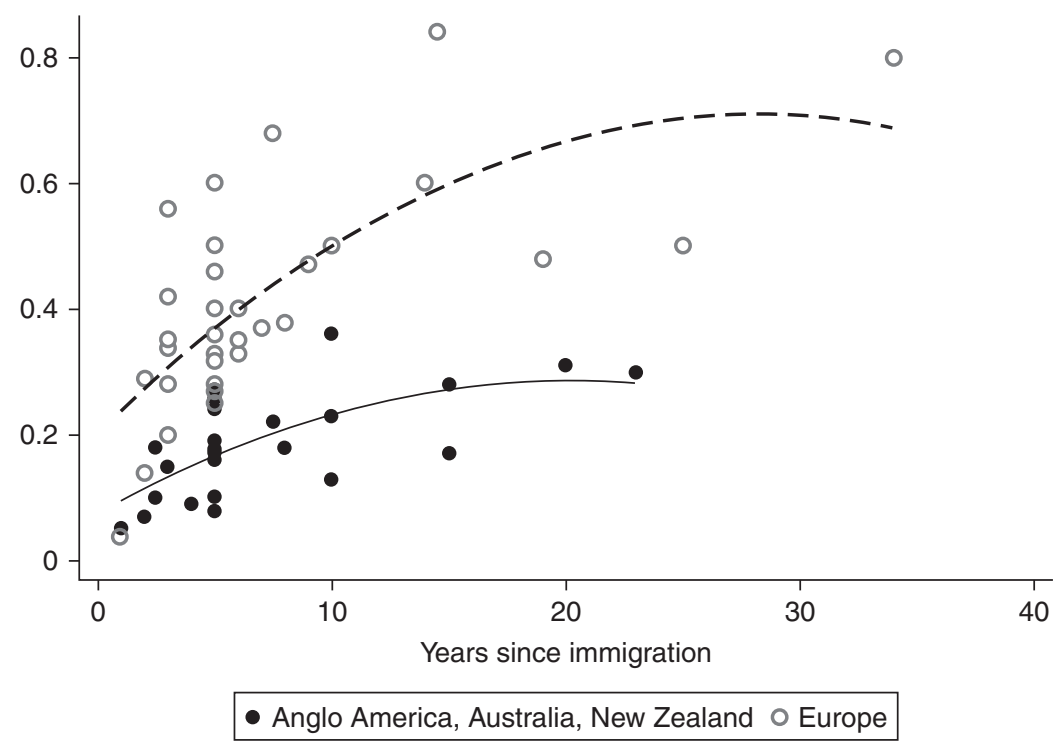

Figure 3.6 Estimated outmigration rates by host region (y-axis, Dustmann and Görlach, 2016).

host than in the origin country. Dustmann and Görlach (2016) develop a general dynamic framework within which return and circulatory migrations can be studied, and discuss various extensions, such as the introduction of shocks to earnings and preferences. The authors emphasize that many choices and decisions of immigrants, such as human capital investment, labour supply or savings, depend on the expected duration of the migration, and that such decisions should therefore be jointly modelled with migration and re-migration decisions.

Structural dynamic models of migrants' decision problems have been developed, for instance, by Colussi (2003), Thom (2010) and Lessem (2013), in which time varying location preferences determine location choices. See also Kennan and Walker (2011) for a dynamic model of internal migration decisions.

\subsubsection{Who Are the Return Migrants?}

The second important question that needs to be addressed is whether there are systematic differences between permanent and temporary migrants. This potential heterogeneity is particularly relevant as it might have important consequences for the host country's demographic and fiscal trends. In particular, several papers have emphasized that, if outmigration is selective, it may affect the analysis of immigrants' earnings assimilation in the host country (see e.g., 
Borjas, 1989, Borjas and Bratsberg, 1996, Lubotsky, 2007, Dustmann and Görlach, 2015).

Borjas and Bratsberg (1996) use a one-dimensional Roy model to explain selective outmigration. There are two reasons for return migration: human capital that has a higher return in the home country is accumulated faster in the host country, and there are unforeseen shocks that result in lower than expected earnings in the host country. The main prediction of the model is that selection of return migrants accentuates the original selection of immigrants to the destination country. In particular, if immigrants are positively selected, then those who stay are likewise positively selected, while if immigrants are negatively selected, then those who remain end up being the worst of the worst.

While Borjas and Bratsberg (1996) implicitly assume a fixed migration duration for all temporary migrants, Dustmann and Görlach (2015) extend the model by allowing a migrant's gain in human capital to vary with the time spent in the host country, and study the implications for the length of migrations. Dustmann et al., 2011 introduce instead a dynamic multidimensional Roy model with return migration, where migrations may occur for the purpose of skill accumulations, or because earnings are higher in the host country, of which the Borjas and Bratsberg (1996) model is a special case.

Some recent data sources report retrospective histories of immigrants (e.g., the Mexican Migration Project dataset). Further, administrative data, especially in Nordic European countries, often include information on year of emigration, the countries of destination, and the migration trajectories back and forth from these countries over time (see Dustmann and Görlach, 2015, for a survey of available data sources).

Evidence on outmigration patterns and selectivity has shown that differences in the probability to return depend on migrants' country of origin, and on the different motives to migrate, that is, whether the focus is on labour migrations, asylum seekers or family migrants (see e.g., Jasso and Rosenzweig, 1982 and Bijwaard, 2010). For instance, using combined Dutch register data at the national and municipal level, Bijwaard (2010) finds that non-Dutch labour migrants display a higher probability of leaving the host country compared to family migrants.

The literature also reports evidence on the relation between educational attainment and the propensity to outmigrate. Using German data from the German Socio-economic Panel (GSOEP) and IAB data on Turkish migrants in Germany, Dustmann (1996) finds that years of schooling increase the probability that a migration is intended to be permanent. However, higher education decreases the residual time spent in the country for those who intend to return. Constant and Zimmermann (2011) claim that more than 60 per cent of the migrants belonging to the countries with which Germany had guest-worker agreements in place engage in repeat and circular migration, and that being 
highly educated reduces the number of exits, while being a male and owning a German passport positively affects the number of exits from Germany.

Reagan and Olsen (2000), using instead longitudinal data from the 1979 cohort of the US National Longitudinal Survey, show that migrants with a higher earnings potential are less likely to outmigrate, though obtaining a college degree increases the possibility of return. Moreover, the authors find that time since migration has a negative effect on the probability of return, while the opposite is true for age at migration.

The nonrandom selection of return migrants has important consequences for their performance in the host country's labour market and for their likely impact on the host country's welfare state. Borjas (1989) uses information from the 1972-1978 Survey of Natural and Social Scientists and Engineers to estimate outmigration rates from the US and finds evidence of lower average earnings of return migrants in comparison with permanent migrants to the US. Lubotsky (2007) takes a more systematic perspective linking information from administrative sources, that is, the US Social Security records, to data from the US Survey of Income and Program Participation and to the Current Population Survey to construct migrants' employment and earnings histories. He finds evidence of both selective return migration and circular migration to and from the US. His results indicate that returnees are characterized by lower than average earnings, and that ignoring selective outmigration leads to an upward bias in the estimates of immigrant earning assimilation.

\section{Open Issues}

The temporariness of migration and the potential selectivity of outmigration opens up a multitude of future research avenues. One recently emerging stream of literature investigates immigrants' assimilation paths in destination countries and models migrants' migration plans in conjunction with their economic decisions, including labour supply and human capital investments (Adda et al., 2015, Dustmann and Görlach, 2016). Such approaches coupled with more and better data will help to push future research in this important area.

\subsection{The Fiscal Effect of Immigration}

Demographic developments (see Section 3.3), as well as the mobility of immigrant populations (see Section 3.4) must be taken into account when studying the fiscal impact of immigration on the host country. This topic has received considerable attention over the past few decades, and the recent financial crisis has contributed to making this debate even more controversial.

The characteristics and preferences of a country's citizens determine its public budget constraint via tax rates corresponding to different levels of 
government spending (Preston, 2014). Immigration may also impact public finances of the host country by increasing a country's workforce and changing the age composition of the population. The fiscal system may not only benefit from immigrants' tax contributions, but may also face a rise in the demand for public services. The literature on migrants' potential fiscal effects on Western countries has followed a variety of different methodologies. Two broad groups of studies can be identified, depending on whether they followed a 'static' or a 'dynamic' approach. In this section we briefly review each of them in turn.

\subsubsection{Static Frameworks}

Static analyses allow us to answer questions such as 'What is the net fiscal contribution of immigrants who arrived after year $X$, compared to natives?' This is a politically important question. The approach essentially compares the immigrants' and natives' utilization of public services, and contrasts this to tax revenues collected from the two groups. This is achieved by combining public accounts information on expenditures and tax revenues with microdata that allow constructing group specific weights for each public account item, so that these can be allocated to different demographic groups, such as immigrants and natives. ${ }^{8}$

We briefly report the main findings from some studies for European countries characterized by different welfare systems, such as Norway, Sweden and Germany. We also review some evidence from the analysis of the overall fiscal effects of immigration to the US, the UK and Sweden.

Bratsberg et al. (2010) use longitudinal administrative register data on male immigrants who arrived in Norway from developing countries between 1971 and 1975, and follow their employment history over time. They report a significant drop in labour market participation rates ten years after arrival, much larger than the decline estimated for the native reference group. The authors also find evidence of high social security dependency rates for those migrants who exit the labour market. Their analysis is extended in Bratsberg et al. (2014) to a larger set of migrant entry cohorts. Unlike immigrants from developing countries, immigrants from Western countries exhibit lifecycle patterns in terms of employment, earnings and welfare dependence that resemble those of natives.

Using a different methodology, Hansen and Lofstrom (2003) study differences in welfare utilization between immigrants and natives in Sweden over the period 1990-1996. Their findings suggest that migrants' welfare benefit utilization patterns become more similar to those of natives as they spend time in the host country. Despite evidence of assimilation, Hansen and Lofstrom (2003) report persistently higher dependency rates for immigrants and a gap that does not disappear even after 20 years spent in the host country. 
Evidence from Germany shows that foreign households display a lower probability of welfare utilization than natives, after controlling for observable socioeconomic and demographic characteristics such as a household's head labour force status, family composition and home ownership (Riphahn, 2004). Using several waves of the German Socioeconomic Panel (1984-1996), Riphahn finds that higher take-up rates for foreign born families are driven by differences in socio-economic characteristics between native and foreign households. She also uncovers a positive trend in welfare take-up by the immigrant population, indicating that welfare utilization increases with time spent in the new country.

Another stream of research uses cross-sectional data to estimate immigrants' net contribution to the fiscal system by simultaneously considering the expenditures and revenues side of the government budget. Drawing information from the 1990 US Census, Borjas (1994) calculates the annual net fiscal contribution of immigrants in the US and finds that they are net contributors to US public government finances. For the UK, Dustmann et al. (2010a) assess the net fiscal contribution of immigration from Central and Eastern European countries (the A8 countries) that joined the EU in 2004 and show that they are not only less likely than natives to receive welfare benefits and to live in social housing, but they are also more likely to be net contributors to the UK public finances, due to higher participation rates in the labour market and lower benefit transfers. Dustmann and Frattini (2014) estimate the net fiscal contribution of immigrant arrival cohorts to the UK since 2000. Overall, immigrants are found to be less likely than natives to receive welfare state benefits or tax credits, and make a positive net fiscal contribution over that period. Ruist (2014) performs a similar analysis for European A10 accession migrants to Sweden and finds results close to those in Dustmann et al. (2010a).

\subsubsection{Dynamic Models}

Dynamic analyses are 'forward looking', computing the net present fiscal contribution of a particular arrival cohort (i.e., the net present value of the stream of future taxes and expenditures over the entire lifecycle corresponding to a given cohort or flow of immigrants). This requires strong assumptions regarding future fertility, employment, government tax rates and expenditures patterns (Rowthorn, 2008). Typical examples of this approach are two papers by Storesletten $(2000,2003)$, which consider the fiscal impact of immigration on the US and Sweden.

Storesletten (2000) develops and calibrates a general equilibrium overlapping generation model to compute the net present value (NPV) to the government of admitting one additional immigrant to the US. The model allows for return migration, which is assumed to depend on the time spent in the host country, but is not endogenously determined, ${ }^{9}$ and for the portability of 
social insurance benefits from the host to the source country in case of return. When comparing an initial situation which allows for migrants' return to the case of no outmigration, the model predicts an increase in government's NPV profiles when admitting highly skilled migrants who are less than 49 years old, while reducing the NPV in the case of other migrant groups (old, unskilled etc.). The intuition for this result is that young, highly skilled workers are net contributors to the welfare state, and restricting their mobility will increase their overall fiscal contribution to the destination country.

Storesletten (2003) extends the analysis focusing on Sweden. He uncovers also in this case potential gains from migration. While the qualitative effects of immigrant's fiscal impact on the host country finances are similar for the US and Sweden, the size of potential benefits from high-skilled migration to Sweden is much smaller than in the US, reflecting important differences between the two countries in terms of labour market outcomes, fiscal burden and size of the welfare state.

A second approach applied to study the long-term effect of immigration is based on the generational accounting technique. This methodology assesses the redistribution of the tax burden across generations by taking into account the lifecycle contributions made by current and future generations; it allows for an in depth analysis of the costs and benefits of immigration in terms of revenues and expenditures and for a comparison of the potential fiscal effects of alternative migration policies. The information needed, however, is substantial and involves reliable demographic forecasts, as well as data on the tax and transfers structure for each demographic group, detailed data and projections on government expenditures, information on the initial stock of public debt etc.

Findings from the numerous papers that have applied this methodology indicate a net fiscal gain if immigrants are highly skilled and relatively young, but the magnitude of the effects depends on institutional features of the destination countries. Auerbach and Oreopoulos $(1999,2000)$ study the fiscal effects of immigration to the US. They find little evidence of either a positive or negative effect of changes in the overall level of immigration on public finances. Only when looking at the impact of skilled immigration do they obtain clear-cut results: an increase in the share of skilled immigrants unambiguously improves the US fiscal position. Chojnicki (2013) carries out a similar exercise focusing on France. His findings indicate a slight positive effect in the long run, mainly driven by the continuous inflows of working age migrants and by the net positive contribution of the descendants of first-generation immigrants. The net gain from immigration is larger if the immigrants entering the country are highly qualified. However, the magnitude of the effects is not large enough to significantly reduce government fiscal imbalances. A more sizable positive fiscal effect of immigration is found by Collado et al. (2004) for Spain, and by Mayr (2005) for Austria. 
The immigrants' impact on the government budget in the host country might have important policy consequences, which have also received some attention in the literature. Razin and Sadka (1999, 2000) develop an overlappinggeneration model where each generation lives for two periods, two types of skills coexist, and a pay as you go pension system is in place, which requires the young generation in employment to finance retirement benefits for the elderly through income taxes. Under the assumption of free capital mobility, ${ }^{10}$ the model predicts a net gain from migration for both low and high income groups and young and old age groups of individuals living at the time of the immigrant flow. This is possible since, in an everlasting economy, the potential net burden immigrants impose on the native population may be indefinitely shifted onwards to the next generation. This result crucially depends on the assumption of free capital mobility, which ensures that factor prices are unaffected. If this assumption is relaxed, Razin and Sadka (2000) show that an anti-immigration sentiment may arise and weaken or even overturn the positive effects of migration: the migrants' net contribution may turn into a loss for some native income groups of both current and future generations.

\section{Open Issues}

The analysis of the fiscal impact of immigration in destination countries still does not systematically include return or circular migration when modelling migrants' net contributions to the host country public finances. Moreover, the assumptions needed for dynamic models of the fiscal impact of immigration, especially in the generational accounting context, are very strong, and predictions are highly sensitive to small changes in these assumptions. For example, in a recent study Bonin et al. (2014) show that the findings of traditional generational accounting exercises are significantly affected when the impact of business cycle fluctuations is taken into account. The more robust approach, with minimal data requirements and at the same time answering politically important questions, is developed by Dustmann and Frattini (2014).

\subsection{Migration and Skill Shortages}

Immigration can - at least partially - offset the effects of a shrinking population. In this section we review research concerned with how the inflow of foreign workers can help to fill labour shortages and bring about skills that are in short supply in destination countries, thus relaxing important bottlenecks leading to inefficiencies in the production of goods and services. ${ }^{11}$

Even if the notions of labour and skill shortages are extensively used by economists and policy-makers, there is no consensus over a universal definition of 'shortage' (see UK Migration Advisory Committee - MAC, 2008, 2010 and Dustmann et al., 2010b). From a theoretical perspective, a shortage arises when supply and demand for a given type of worker are not in equilibrium and 
the demand is greater than the supply. ${ }^{12}$ In this context, a shortage of workers is resolved if wages increase to balance demand and supply. Labour market failures, however, may generate shortages due to factors unrelated to the economic cycle and, although wage increases may affect native population skill-specific human capital investments in the long run, it may take several years before the economy reaches the equilibrium. Moreover, labour market imperfections such as wage rigidities in specific sectors (e.g., the public sector) may make equilibrium adjustments harder and lead to persistent shortages of workers in specific occupations (see MAC, 2010).

Two major approaches have been adopted to identify and measure shortages: a microeconomic perspective focuses on the employers' viewpoint, whereas a macroeconomic approach relies on aggregate indicators such as wages (see MAC, 2008). Current methodologies to identify and forecast labour and skill shortages often use a combination of the two, relying on macro-level modelbased projections, on sectoral and occupational studies and on stakeholder surveys.

Descriptive findings from Europe reveal shortages in various occupations, across a broad spectrum of skill levels. Table 3.2 ranks occupations according to the 'bottleneck' vacancies ${ }^{13}$ reported by employers in European countries, ${ }^{14}$ and summarized in a recent study carried out by the European Commission (European Commission, 2014b). Among the most affected groups, we have both occupations which require a highly qualified workforce, such as cooks or engineering and health professionals, ${ }^{15}$ as well as low-skilled occupations, such as waiters and heavy truck and lorry drivers. Occupations experiencing shortages are not only those characterized by growing employment, but also those in sectors which have been severely hit by the recent economic crisis, such as manufacturing and construction.

In order for a migration policy to be effective in addressing a labour market shortage, policy-makers should be able to design and develop a selection process able to attract the required type of migrants in a sufficiently short time, and to direct foreign workers towards the parts of a country where they are mostly needed (International Organization for Migration, 2012). Countries that have in place specific policies to attract skilled workers employ a wide array of instruments, which can be broadly classified as 'immigrant driven' or 'employer driven' (Chaloff and Lemaitre, 2009), and which focus on addressing temporary or permanent needs. In an 'immigrant driven' system, a foreigner is admitted without necessarily having a job offer in hand, and the selection is based upon a set of desirable attributes. In an 'employer driven' system, on the other hand, the worker must have already received a job offer in order to gain admission.

'Immigrant driven' systems use 'point assessment' to determine how desirable a foreign national is. This type of framework was first used in Canada in 1967, followed by Australia in 1989 and New Zealand in 1991 and more 
Table 3.2 Top 20 bottleneck vacancies in European countries (European Commission, 2014b, p. 9)

\begin{tabular}{cl}
\hline \hline Rank & Specific occupation \\
\hline 1 & Cooks \\
2 & Metal working machine tool setters and operators \\
3 & Shop sales assistants \\
4 & Nursing professionals \\
5 & Heavy truck and lorry drivers \\
6 & Welders and flamecutters \\
7 & Mechanical engineers \\
8 & Software developers \\
9 & Specialist medical practitioners \\
10 & Carpenters and joiners \\
11 & Commercial sales representatives \\
12 & Electrical engineers \\
13 & Waiters \\
14 & Civil engineers \\
15 & System analysts \\
16 & Primary school teachers \\
17 & Plumbers and pipe fitters \\
18 & Accountants \\
19 & Building and related electricians \\
20 & Health care assistants \\
\hline \hline
\end{tabular}

recently by the UK, Denmark and, to a lesser extent, the Netherlands. The selection process is based on the stipulation of a 'pass rate' and points are attributed based on a set of five main criteria: occupation; work experience; education; destination country language proficiency and age. A second set of criteria might also be used, including: employer nomination/job offer; prior work in the destination country; education obtained in the destination country; settlement stipulations; and presence of close relatives and prior earnings (Facchini and Lodigiani, 2014). ${ }^{16}$

Broadly speaking, two different economic models lie behind the attribution of 'points' to the first set of criteria. On the one hand, we have a short-term approach, which emphasizes the need to fill current gaps in the destination country's labour market. In this framework, the applicant's recent occupation and work experience are particularly highly rewarded. On the other hand, we have a longer term approach, that is, a model based on the earnings capacity of immigrants, where education, age and official language proficiency are the main focus.

In 'employer driven' skilled immigration systems - like the US H1-B visa system or the current UK Tier 2 system - the focus is typically on temporary work permits, ${ }^{17}$ and employers play a key role. They offer the migrant a job, 
sponsor his/her application and often carry out a 'labour market' test, whose purpose is to establish that the vacancy advertised cannot be filled by a local worker. The stringency of such tests varies substantially depending on an array of country specific factors.

Even if selection based on skill involves only a limited share of the total number of migrants admitted by Western destination countries, the existing literature suggests that migrant-driven schemes have been successful in rasing the skill level of the average migrant (Aydemir and Borjas, 2007, Aydemir, 2011). However, the evidence on employer driven schemes is ambiguous. Some countries have successfully deployed these frameworks to retain the best and brightest foreign students, graduating from their universities. The U.S. US H1B scheme is a well-known example, and the literature has emphasized the role of immigrants admitted through this programme in promoting innovation (Kerr and Lincoln, 2010). As for other destinations less successful in attracting foreign students, such as some continental European countries, the employerdriven model has shown important limits, in particular when it comes to the identification of suitable candidates (Facchini and Lodigiani, 2014).

Over the past several years, the EU has become increasingly aware of the role that high-skilled migration may play in addressing labour market shortages. To systematically regulate and promote high-skilled migration by allowing access to the EU wide labour market, the European Council has introduced in 2009 a Directive on 'the conditions of entry and residence of third-country nationals for the purpose of highly qualified employment' (Directive 2009/50/EC), but its effect has not yet been thoroughly investigated (Facchini and Lodigiani, 2014).

Labour and skill shortages are often geographically localized, as destination countries face a population concentration in urban centres and depopulation in rural areas. Immigration may thus help to balance geographical mismatches within national labour markets, but the results have been mixed (International Organization for Migration, 2012). At the same time, some evidence indicates that by being more geographically mobile within the destination country, migrants might help address local labour shortages. For instance, Borjas (2001) emphasizes the 'greasing' effects that immigration may have in the wheels of the labour market by bringing a workforce that is highly responsive to different wages and economic opportunities across regions. Interestingly, empirical evidence for the US indicates that foreign migrants do play an important role in speeding up the process of wage convergence and in helping the national labour market reach an efficient allocation of resources. Similar evidence has been uncovered by Dustmann et al. (2010b) for the UK.

One important caveat to bear in mind when addressing shortages via migration, is that there might be potentially negative effects in the long run. In particular, complete reliance on foreign workers may lead to dependence on them and generate perverse effects. For example, employers might end up adopting less 
advanced, labour intensive technologies, and in order to remain competitive they will continue to require migrants in the future, contributing to the creation of new shortages (see e.g., Martin and Ruhs, 2011, International Organization for Migration, 2012).

\section{Open Issues}

Better tools, based on robust conceptual models, are needed to identify and measure labour and skill shortages at both the national and subnational level. Better data will certainly help. The development of effective policies to address shortages requires understanding the short- and the long-term effects of international migrants' recruiting and how they compare with available alternatives. Much more work is needed in this area.

\subsection{International Migration and the Health Care Sector}

In the previous section, we have argued that migration can be a short-term solution to skill shortages affecting destination countries' labour markets. We now turn to two specific sectors, health care and old age care. We start by investigating the role of immigrants as suppliers of those services (Subsections 3.7.1 and 3.7.2), and turn next to considering their impact on the demand side of this market (Subsection 3.7.3).

\subsubsection{International Migration of Health Care Professionals}

Migrant workers play an increasingly important role in the health care sector. Immigration is often seen as the quickest and cheapest solution to perceived short-term shortages in the availability of medical staff. Foreign trained workers may also be important in addressing local shortages in underserved and/or rural areas or in case of shortages in specific medical specialties, for example, those related to an ageing population. Moreover, Western countries are starting to use foreign health care professionals to address the needs of an increasingly diverse population whose health needs may be more efficiently met by an ethnically diverse medical staff (see Grignon et al., 2013 for a recent review).

Major suppliers of health-care workers are African countries, India and the Philippines, whereas destination countries who have historically recruited large numbers of foreign trained health professionals are Australia, Canada, the UK and the US (Bach, 2003). Recent data collected by the World Health Organization (WHO, 2014) show that employing immigrants in the health industry $^{18}$ is becoming more widespread (Table 3.3). By 2008, almost half of the nurses employed in Ireland were foreign trained, and the same is true for over a third of the doctors registered there. In New Zealand, almost 39 per cent of the doctors are foreign trained, and so are almost a quarter of the nurses. At 
Table 3.3 Foreign-trained (or foreign) nurses and doctors in selected OECD countries, based on professional registries (WHO, 2014, p. 87)

\begin{tabular}{|c|c|c|c|}
\hline & Year $^{a}$ & Number & Share $(\%)$ \\
\hline \multicolumn{4}{|l|}{ Nurses } \\
\hline \multicolumn{4}{|l|}{ Foreign-trained } \\
\hline Finland & 2008 & 530 & 0.5 \\
\hline Netherlands & 2005 & 3479 & 1.4 \\
\hline Sweden & 2007 & 2585 & 2.6 \\
\hline US & 2004 & 100791 & 3.5 \\
\hline Denmark & 2005 & 5109 & 6.2 \\
\hline Canada & 2007 & 20319 & 7.9 \\
\hline United Kingdom & 2001 & 50564 & 8 \\
\hline New Zealand & 2008 & 9895 & 22.1 \\
\hline Ireland & 2008 & 37892 & 47.1 \\
\hline \multicolumn{4}{|l|}{ Foreign } \\
\hline Belgium & 2008 & 2271 & 1.5 \\
\hline France & 2005 & 7058 & 1.6 \\
\hline Portugal & 2008 & 2037 & 3.6 \\
\hline Italy & 2008 & 33364 & 9.4 \\
\hline \multicolumn{4}{|l|}{$\overline{\text { Doctors }}$} \\
\hline \multicolumn{4}{|l|}{ Foreign-trained } \\
\hline Poland & 2005 & 734 & 0.6 \\
\hline Austria & 2008 & 1556 & 4.1 \\
\hline France & 2005 & 12124 & 5.8 \\
\hline Denmark & 2008 & 1282 & 6.1 \\
\hline Netherlands & 2006 & 3907 & 6.2 \\
\hline Belgium & 2008 & 289 & 6.7 \\
\hline Finland & 2008 & 2713 & 11.7 \\
\hline Canada & 2007 & 14051 & 17.9 \\
\hline Sweden & 2007 & 6034 & 18.4 \\
\hline Switzerland & 2008 & 6659 & 22.5 \\
\hline US & 2007 & 243457 & 25.9 \\
\hline United Kingdom & 2008 & 48697 & 31.5 \\
\hline Ireland & 2008 & 6300 & 35.5 \\
\hline New Zealand & 2008 & 4106 & 38.9 \\
\hline \multicolumn{4}{|l|}{ Foreign } \\
\hline Slovak Republic & 2004 & 139 & 0.8 \\
\hline Japan & 2008 & 2483 & 0.9 \\
\hline Greece & 2001 & 897 & 2.5 \\
\hline Italy & 2008 & 14747 & 3.7 \\
\hline Germany & 2008 & 21784 & 5.2 \\
\hline Portugal & 2008 & 4400 & 11.1 \\
\hline Norway & 2008 & 3172 & 15.9 \\
\hline
\end{tabular}

a Notes: Country data sources: Austria: Austrian Medical Chamber; Belgium: Federal Public Service Health, Food Chain Safety and Environment; Canada: CIHI Workforce Trends of Regulated Nurses in Canada, SMDB Scott's Medical Database; Denmark: Labor Register for Health Personnel, National Board of Health, Nursing Adviser; Finland: National Supervisory Authority for Welfare and Health (Valvira); France: ADELI, DREES, Ordre des Médecins; Germany: Bundesärztekammer; Greece: General Secretariat of the National Statistical Service of Greece; Ireland: An Bord Altranais, Irish Medical Council; Italy: AMSI Associazione Medici di Origine Straniera, based on ENPAM, Federazione Ipasvi; Japan: Statistic Bureau, Ministry of Internal Affairs and Communication; Netherlands: BIG Register (Beroepen in de Individuele Gezondheidszorg); New Zealand: Ministry of Health, Information Directorate, Nursing Council of New Zealand; Norway: Den Norske Legeforening; Poland: Polish Chamber of Physicians and Dentists; Portugal: ACIDI, I.P., Immigration Observatory, Ordem dos Enfermeiros; Slovak Republic: Ministry of Health of Slovak Republic; Sweden: Swedish National Board of Health and Welfare; Switzerland: FMH Swiss Medical Association; UK: General Medical Council, Nursing and Midwivery Council; US: American Medical Association, National Council of State Boards of Nursing (NCSBN). 
the same time, the US continues to remain the main destination of medical professionals, with over 100,000 foreign trained medical doctors and almost a quarter of a million foreign trained nurses. Important differences exist though among the OECD countries for which data are available. In particular, Nordic European countries report very small numbers of registered foreign medical professionals, and in many Eastern European countries the number of foreign trained professionals is negligible.

The arrival of foreign medical professionals has both short- and long-term consequences on the host country's labour market. In particular, it may affect the employment and wages of natives in the sector and, importantly, it might have a significant impact on the overall quality of the health care services provided.

Most of the existing evidence comes from the US. Combining data from the National Survey of Registered Nurses and data from the Current Population Survey for the period 1995-2008, Schumacher (2011) studies earnings differentials between foreign-born/trained and native nurses and the effects of foreign nurses' immigration on natives' wages. He finds evidence of a negative wage gap only for recent immigrants and of a very small, if any, negative effect of immigration on native wages. Cortés and Pan (2014) also analyse the labour market impact of foreign health professionals. Following Card's (2001) spatial correlation approach, they exploit the variation in the distribution of foreign nurses across US cities and across labour market experience groups within cities. They find a large displacement of native nurses and provide evidence that the crowding out is due to natives changing occupation or to individuals deciding not to enter the nursing profession at all. The overall wage effect is instead negligible even if immigration might lead to a deterioration in working conditions.

Given the specific status of the health-care industry, a particularly important question often at the heart of the debate on the migration of health care professionals concerns the 'quality' of human capital supplied by migrants. Dustmann and Frattini (2011) find that immigrants employed in the public sector in the UK have on average more years of education than natives, which suggests that immigrants may positively affect the 'quality' of public services provided.

Cortés and Pan (2015) tackle this important issue by comparing foreign educated and native born nurses in the US. Interestingly, they find a positive wage gap for Filipino nurses, whereas no significant wage premium is found for nurses educated in other countries. Moreover, the positive wage gap for Filipino nurses cannot be explained by socio-demographic or economic characteristics, thus suggesting that it is driven by unobserved positive human capital attributes. Cortés and Pan (2015) conclude that the 'high quality' of Filipino nurses is likely to be driven by a strong positive selection into the profession in the country of origin. 
Besides selection in the country of origin, the high 'quality' of foreign health care professionals is likely to be driven also by the strict rules put in place in immigrant destination countries, which severely limit access to health-care professions and often discriminate against foreigners. Several papers have tried to study the extent these policies are in place to respond to legitimate public concerns, or rather respond to pressures by native physicians to limit competition in the sector. Also in this case, the main evidence comes from the US.

Glied and Sarkar (2009) focus on the institutional factors affecting the size of the International Medical Graduate (IMG) population in the US, and assess the medical profession's role in shaping it. To this end, they construct estimates of the stringency of the tests required for foreign educated professionals over time and combine it with evidence on the underlying IMG cohort characteristics taken from Census data. They then investigate the quality of different cohorts of foreign graduates and construct an indicator for the 'rate of return' to the investment in human capital in the medical profession over time. Interestingly, their analysis suggests that in setting the pass rate for the medical licensing examination required for the IMGs, the medical profession tries to maintain a constant rate of return to the human capital investment of domestic doctors.

The role of medical associations in shaping access to the profession has been investigated also in a recent paper by Peterson et al. (2014), exploiting US crossstate variation in licensing requirements for foreign educated physicians over the period 1973-2010. The authors find that states with self-financing - rather than state government - funded medical boards end up with stricter rules for migrant licensing, and in particular foreign trained doctors require lengthier residency training in the US in order to gain access to the profession. The role of relicensing requirements in creating rents for native health professionals is also analysed by Kugler and Sauer (2005) using quasi-experimental data from Israel.

The migration of health care professionals has received considerable attention also in the development literature, and much has been written to assess whether it creates a 'brain drain' or a 'brain gain' for the source country. While this issue is very important, it goes beyond the scope of this survey and we refer the interested reader to the excellent review by Docquier and Rapoport (2012).

\subsubsection{International Migration of Old Age Carers}

Population ageing in Europe is expected to significantly increase the demand for long-term care (LTC). While the international flow of highly skilled health professionals has received a lot of attention in the literature, much less is known about the migration of old-age care workers. 
Employment in the LTC sector continues to be female-dominated in most EU Member States (Bettio and Verashchagina, 2012). However, different patterns in the division of care work between the state, the private market and the family have given rise to a variety of models of care, in which foreign migrants play a very different role.

In what follows, we provide an overview of the different long-term care regimes, and compare their main features, focusing on the role of migrants and their employment conditions. While little is known of the direct effect of immigrant workers on natives employed in the same sector, a few studies have highlighted the impact of migration on the labour supply decisions of younger and possibly better educated Europeans, who would otherwise have been in charge of caring for their elderly family members.

\section{Models of Long-Term Elderly Care}

Migrants' role in LTC provision varies with the destination country traditions and institutional contexts. Three main arrangements have been identified in the literature.

Broadly speaking, a 'migrant in the family' model characterizes Southern European countries. In this context, care for the elderly is typically not delegated to private or public institutions, remaining instead the responsibility of the family (see Bettio et al., 2006). Italy is a fitting example of this tradition. A large demand for care workers, and a limited supply of native providers, has led many Italian families to rely heavily on migrant workers to manage family care needs. The majority of workers in this sector come from Eastern Europe (Van Hooren, 2012). They are typically middle-aged females, with children and family left in their origin country. This type of migration is often temporary or rotational, with migrant women regularly visiting their origin country to maintain ties with their families left behind (Bettio et al., 2006). Migrants' employment conditions vary substantially, and are highly sensitive to their legal status (Van Hooren, 2012).

Two additional models of care are common in other Western European countries. The United Kingdom represents the so-called 'migrant in the market' case, where access to publicly provided services is means-tested and highincome people often have to purchase care services on the market. Within this framework, migrants are often employed in the private formal sector, rather than in the informal or public sectors. Foreign workers' employment conditions, however, are found to be on average worse than those of natives and carers employed in the public sector. In particular, migrants are more likely than natives to work longer hours and do night shifts (Van Hooren, 2012). The last model is prevalent in the Netherlands and in Nordic countries, where citizens are entitled to publicly financed services. Care services are provided by private organizations, working in close collaboration with the government. In 
this context, the proportion of immigrants is much lower than in the other two regimes and their employment conditions are typically comparable to those of native workers.

\section{Care Workers and Highly Skilled Natives' Labour Supply}

Besides directly addressing specific needs for long-term elderly care, the availability of immigrant care workers - and more generally of low-skilled domestic workers - is likely to impact the native labour supply and, in particular, the employment decision of highly skilled women. The available empirical evidence, building both on US and European data, indicates a positive impact of low-skilled immigration on the labour supply of highly skilled native women.

Cortes and Tessada (2011) provide evidence from the US, using data from the 1980, 1990 and 2000 Census. In particular, they find a positive effect of low skilled immigration on the number of hours worked per week by women in the top quartile of the female wage distribution. They also show that this positive effect decreases in size and significance for women at lower points of the wage distribution, becoming insignificant for those with wages below the median. Importantly, immigration affects mainly the intensive margin, that is, the number of hours worked, whereas no significant effect is found on the extensive margin, that is on the probability to enter the labour market. The former effect is particularly large for occupations demanding long hours of work, like law, medicine and research. Similar results have been found, using Italian data, by Barone and Mocetti (2011) and using Spanish data by Farré et al. (2011).

\subsubsection{Immigrants' Demand for Health Care}

As migrants represent an increasing proportion of the European population, we need a better understanding of their health patterns and their access to health care. For many European health systems, equity in access remains a fundamental objective, and understanding the impact of immigrant flows on the sustainability of existing public health care systems is an important policy priority.

Traditional models for the demand for health care have highlighted the main factors able to explain differences in access to health services by groups of individuals. Predisposing characteristics (such as socio-demographic status and health beliefs), enabling factors (such as personal/family and community characteristics like income and health insurance systems), need variables (both perceived and assessed needs) and characteristics of the health care system have been identified as the main drivers of the demand for health services.

Health care demand is a derivative of migrants' health. Many studies report that immigrants have a good health status at their arrival in the host country (see e.g., Kennedy et al., 2006, Fennelly, 2007). The so-called 'healthy migrant effect', however, tends to disappear once individuals' demographic 
characteristics such as age are accounted for. Moreover, once in the host country, immigrants' exposure to risk factors such as poverty and exclusion may deteriorate their mental and physical health status (see WHO, 2010).

Evidence on immigrants' health is scarce, given the lack of exhaustive and cross-country comparable data on health status (see e.g., Ingleby, 2009, Nielsen et al., 2009). Where data are available, large heterogeneity is found in migrants' health depending on age, gender, country of origin, legal status and economic wellbeing (see Rechel et al., 2011). Overall, however, migrants appear to be particularly vulnerable to communicable diseases (see Carballo, 2009a), report higher rates of accidents at work and work-related diseases (see Carballo, 2009b) and a higher incidence of mental illnesses (see Ingleby, 2008) compared to the native population. Evidence of higher maternal and infant mortality is also found in some destination countries (see the overview by Bollini et al., 2009, Carballo, 2009b). The migrants' higher vulnerability to specific diseases can be partly explained by migration-related traumatic events, health conditions in the country of origin and migrants' over-representation in occupations characterized by low wages and poor working conditions (see the overview by Gushulak et al., 2010).

The empirical literature also emphasizes a substantial heterogeneity in access to health care across countries, with much emphasis on the provision model. In the US, where health care is dominated by the private sector and traditionally health insurance coverage has not been universal, the empirical literature has looked at both differences in health insurance takeup between migrants and natives, and at their respective use of health care services. In an interesting study, Akresh (2009) examines the utilization patterns of Asian and Hispanic immigrants included in the 2003 New Immigrant Survey (NIS) and finds that duration of residence, knowledge of host country language, and being insured increase immigrants' access to health care services. This evidence confirms previous findings by Leclere et al. (1994), using data from the 1990 National Health Interview Survey.

Unlike in the US, health care provision in Europe is dominated by a model based on universal coverage. Most EU Member States extend health coverage to third country nationals, but the empirical evidence suggests that inequalities in access and health status between migrants and natives are pervasive also in Europe (see e.g., Ingleby et al., 2005, Mladovsky, 2007), even though the patterns differ substantially across countries.

Solé-Auró et al. (2012) carry out a cross-country analysis of the patterns of utilization of health services among elderly migrants and natives and find that immigrants significantly over-utilize health care services compared to natives, even after controlling for socio-economic and demographic characteristics.

Other studies focus on specific types of health services. The evidence on the usage of general practitioners' health care services does not exhibit a clear 
pattern: some papers emphasize a over-utilization by the immigrant or minority ethnic population (see e.g., Smaje and Le Grand, 1997, Reijneveld, 1998, Winkelmann, 2002, Morris et al., 2005, Uiters et al., 2006), which is almost completely explained though by gender and health status, whereas other researchers find no significant differences in primary care use between migrants and nonmigrants (see e.g., Antón and De Bustillo, 2010, Wadsworth, 2013) or even under-utilization of primary health care services by migrants (see e.g., Gimeno-Feliu et al., 2013). Overall, these studies suffer from a lack of detailed, comparable data across countries. A similar inconclusive picture emerges from the study of the usage of specialist and hospitalization services. However, a consistent pattern emerges when it comes to access to preventive care. Women and undocumented migrants appear to face significant barriers. In particular, migrant and ethnic minority women are found to have difficulties in accessing prenatal care services, as well as cancer screenings (see e.g., Webb et al., 2004, Wolff et al., 2008, McCormack et al. (2008), Moser et al. (2009), Price et al., 2010). Similarly, the existing evidence indicates that migrants tend to over utilize emergency services compared to natives (see Dyhr et al., 2007 for Denmark and Cots et al., 2007 for Spain).

\section{Open Issues}

The studies we have reviewed highlight that we have a good understanding, at least for some countries, of the effect of immigration on the supply of skilled health care professionals, and on how they impact the destination country's labour market.

More work is needed to understand the impact of LTC workers. In particular, we need better individual level data on both the migrants themselves and the native households benefiting from their services. Given the often informal nature of work arrangements in this area, collecting these data will not be an easy task. As for the analysis of the impact of migration on the demand side of health care services, a large array of studies exist, but there is clearly a need to improve the cross-country comparability of the data used in the analyses, to better understand the sources of the significant differences reported in the various studies we have reviewed.

\subsection{The Floridization of Europe: Old Age North-South Migration}

The relatively recent phenomenon of amenity led migration of retirees from Northern European towards Mediterranean coastal areas is likely to have important consequences on the demographic structure, health care demand and provision and more generally the working of welfare states in both source and destination countries. 
Little systematic evidence exists on intra-European old age migration, but several studies have considered late-age migration within the US. We will review this evidence, which will help identify the important questions that need to be addressed in the European context. In Section 3.8.1 we consider the existing evidence on the drivers of old age migration. We turn next to considering the effects of retirement migration on destinations (Section 3.8.2).

\subsubsection{Determinants of Old Age Migration}

A useful conceptual framework to understand the main forces at play in shaping old age migration decisions has been developed by Litwak and Longino (1987). Three main stages are identified: the first occurs at retirement, and the migration decision is driven by the maximization of utility, which depends upon environmental and lifestyle amenities. At this stage migrants are likely to be married, in good health and wealthy. The second stage is characterized by a decline in the health status and the potential loss of the spouse. Migration is mainly driven by the need to migrate back to the origin country to be close to the family. Finally, in the last stage the migrant needs permanent care, the health status has declined and the individual moves into structures providing formal care to the elderly.

Conway and Houtenville (1998) develop a theoretical model for the migration of the elderly, which takes into consideration the role of government policies, with a focus on state or local fiscal policies. By estimating out-migration and in-migration equations using US data, the authors conclude that state government public expenditures on education, as well as crime levels and taxation on property and income are important determinants of elderly migration behaviour. Gale and Heath (2000) extend Conway and Houtenville's model by decomposing state revenues and spending. Interestingly, they find that elderly migrants are more likely to move towards states where the costs of public government policies are mainly borne by individuals who are still active in the labour market. The composition of local revenues and spending is found to play an important role also at the county level (Duncombe et al., 2001).

In order to analyse the role of age-related heterogeneous effects, some empirical studies divide the elderly population into subgroups. Conway and Houtenville (2003) examine patterns of elderly migration by age groups using data from the 1990 US Census. Younger elderly migrants' location decisions are mainly affected by characteristics such as the presence of specific amenities, climate and government fiscal policies; older migrants are more likely to react to push factors driving them out of their origin state, such as income and property taxes and the cost of living in their origin country.

Among the main determinants of elderly migration, the portability of social security benefits ${ }^{19}$ between source and destination countries is likely to play a key role in affecting, for instance, how return migration (see Section 3.4) 
impacts the fiscal cost of ageing in destination countries (see Section 3.5). While this question is receiving growing attention in the literature (see Holzmann and Koettl, 2015), our understanding of the actual role of portability is limited, even though 'bad experiences' with the portability of welfare benefits have been found to reduce the likelihood to move abroad for professional reasons, whereas 'good experiences' tend to increase it (d'Addio and Cavalleri, 2015). To understand the main difficulties involved in transferring across borders social security entitlements, note that social security benefits are characterized by both a pre-funded and a redistributive component. The latter is particularly important for European countries, where the welfare state is also relatively more generous compared to other immigrant destinations. The separation and identification of each component of a benefit is fundamental in order to make the pre-funded component readily transferable across countries, and informs also the need to set up bilateral or multilateral agreements to coordinate the mobility of the redistributive component.

The existing arrangements imply that international migrants who move for work reasons and then decide to retire in the host country have their portability rights more clearly regulated and are in a better position than those who decide to migrate after retirement (see e.g., Ackers and Dwyer, 2004, Dwyer and Papadimitriou, 2006). Under EU regulation, migrants' social status and rights to claim welfare benefits in the host country strongly depend on their relations with the host country labour market. In particular, economically inactive individuals' right to reside in the host country is constrained by a 'resources requirement ${ }^{\prime 20}$ according to which migrants must provide proof that they have sufficient resources not to become a burden on the host country welfare state. At the same time, elderly migrants' decision to return home after some time spent in the host country may not entitle them to the rights they could have enjoyed in their origin country before departure, since entitlement to specific benefits may require proof of habitual residence (Dwyer and Papadimitriou, 2006). This translates into large numbers of migrant retirees who do not regularize their position since they fear there might be difficulties if at some point they decide to migrate back to their origin country. Moreover, elderly migrants fear that by regularizing their position they may lose some of the benefits they would otherwise be entitled to (see Dwyer, 2000, Legido-Quigley and La Parra, 2007).

\subsubsection{Effects on Host Country Economy}

Late-age migration flows might have significant effects on the host country economy, but little systematic evidence exists on this issue, and most of the existing studies focus on the US. 
Overall, late-age migration appears to have positive effects on the destination's economy, at least in the short run, and some US sunbelt and coastal states have progressively adopted aggressive policies to attract wealthy and relatively young retirees (Haas and Serow, 2002). The positive effects for the host communities are mainly associated with the increases in overall demand and tax payments. However, in the long run, migrant retirees may increase the demand for health care and long-term care services. The net effect on the destination's public finances has not yet been exhaustively studied, even though some attempts have been made, by separately considering old age and young age retirees. In particular, using data from the Bureau of Labor Statistics' Consumer Expenditure Survey, Stallmann et al. (1999) find an overall positive fiscal impact of both young and old elderly migrants, with the rise in local government expenditures being covered by the increased revenues, even in the case of older elderly.

To reach more general conclusions on the long-term economic effect of retirement migration, further research is needed. In particular, more information should be made available and included in the analysis of whether elderly migrants return back to their origin country once they have to rely on family or formal assistance.

\section{Open Issues}

Even if most observers expect intra-EU amenity-led migration to become increasingly important over the coming decades, very little is known about who migrates and about the effects of elderly European migration on the destination countries. Much of our ignorance is due to the lack of systematic data in this area so more efforts should be devoted to fill this gap.

\subsection{Conclusions}

Demographic developments in Europe and beyond, the rapid increase in population flows, both within Europe and between Europe and the rest of the world, and their consequences for the provision of health care services raise a host of vitally important policy questions reviewed in this survey. Several elements emerge from our discussion.

First, existing work addresses most of the issues we have discussed in isolation. Only few papers have attempted to develop general frameworks to capture the interactions between demographic changes, migration and health care provision. More work is required to develop richer theoretical models and empirical analysis to understand the interplay between these different forces, taking into account that they are intrinsically dynamic in nature.

Second, on the measurement side, our analysis has identified several key critical areas where more research is needed. Our current understanding of 
migration and population dynamics is shaped by our limited ability to systematically track individuals over time and across different countries. Existing administrative data sources allow in principle to trace individuals across national borders, but few efforts have been made to link them. When complemented by cross-border surveys, linked individual level administrative data would enable tremendous progress in the study of migration movements both towards and within the EU. Overcoming data limitations should be a priority if we want to better understand the issues covered in our survey.

Third, our analysis has argued that immigration plays a key role in providing a flexible response to short-term skill shortages, and in particular, for the health care sector and for long-term care services. While progress has been made in understanding the impact of foreign care workers on the destination country's labour force, the existing evidence is still rather sparse, and more work is needed to assess the impact and future importance of migration on the health sector and care services.

Finally, population ageing in a common market where people are free to move is likely to lead to migrations of individuals looking for better amenities while retired. The phenomenon has been ongoing for several decades in the US, and we have some basic understanding of the drivers and consequences of old age migration for the sun-belt states. However, little is known about the European context, where the flows of elderly migrants to the Mediterranean is increasing. More work is needed in this area, and data allowing us to capture individual level migration histories would greatly facilitate the analysis.

\section{Acknowledgements}

We would like to thank Laurent Aujean, Bernt Bratsberg, David Coleman, Patricia Cortes, Tommaso Frattini, Libertad Gonzales, Alessandra Venturini and Philip Verwimp for their comments on previous drafts. We would also like to thank Barbara Chizzolini, Marc Ivaldi and Marianne Paasi for their encouragement and the organization of the COEURE workshop, and acknowledge funding by the FP7/320300 grant under the FP7 SSH research programme.

\section{Appendix}

\section{Glossary of Terms}

- Brain drain is defined as the reduction in the per capita human capital in the emigration country (see Dustmann et al., 2011).

- Circular/repeat migration refers to the systematic and regular movement of migrants back and forth from their country of origin towards foreign countries. 
- Destination/host country refers to the place where the migrant has settled.

- Immigrants are identified as individuals born in a different country from the one they live in. ${ }^{21}$

- Net migration is the difference between the inflow and the outflow of individuals over a given period. In most official statistics, inflows and outflows include both the native born and the foreign born.

- Origin/source country refers to a migrant's country of birth.

- Outmigration refers to migrants moving out of the host country either to return to their country of origin (return migration) or to move onwards towards a third destination.

- Replacement (fertility) rate is the total fertility rate per woman which generates the stability of a population under the hypothesis of no migration flows and unchanged mortality rates. This is estimated by the literature at about 2.1 children per woman for most countries, although it may vary slightly with mortality rates.

- Return migration refers to re-migration from the host country back to the country of origin by the migrant's own choice (see Dustmann, 2000).

- Total fertility rate is an indicator of the level of fertility calculated by summing age-specific birth rates over all reproductive ages. In a specific year, it refers to the number of children that would be born to a woman if she were to live to the end of her fertile years and if throughout her life she were subject to the age-specific fertility rates observed in a given year.

\section{Notes}

1. Germany is a leading example of this phenomenon, as pointed out by The Economist on 15 June, 2013. For more details, see http://www.economist.com/news/specialreport/21579148-overcome-its-skills-shortage-germany-needs-remodel-itssociety-erasmus-generation.

2. We follow most of the existing literature in measuring ageing by looking at the evolution of the share of the population aged 15-64 in the total. For an alternative definition, see Sanderson and Scherbov (2010).

3. The figure includes both immigrants born in other EU/Euro member countries and immigrants born elsewhere.

4. Net migration is measured as the difference between the total population on 31 December and 1 January for a given calendar year, minus the difference between births and deaths (or natural increase).

5. Projection estimates are carried out starting from the EUROPOP2013 demographic projections by Eurostat.

6. See the original paper for the sources of the data used to produce the figure.

7. Migration policies play an important role in shaping the length of the migration spell. For more on this, see Section 3.6.

8. See Dustmann and Frattini (2014) for an application, and a detailed explanation of this approach. 
9. See Kirdar (2012) for an extension of the model in which outmigration is endogenized.

10. This assumption ensures that factor returns are not affected by migration.

11. One important caveat to bear in mind though is that - as pointed out by the OECD (2014) and the European Commission (2014b) - less than 40 per cent of the migrants coming to the EU from outside the area gain access to it for work related reasons. The most important channel is instead family reunification.

12. Shortages are therefore the result of a disequilibrium condition in which a labour market does not clear.

13. Bottleneck occupations are defined at the ISCO 4 digit level and are 'occupations where there is evidence of recruitment difficulties, that is, employers have problems finding and hiring staff to meet their needs' (European Commission (2014b) Report on 'Mapping and Analysing Bottleneck Vacancies in EU Labour Markets', p. 7).

14. The sample includes EU Member States, Iceland, Liechtenstein and Norway.

15. See Section 3.7 for a detailed analysis of the health sector.

16. For a recent proposal on the construction of an 'optimal' point-based system, see by McHale and Rogers (2009).

17. Change of status is often allowed though, as in the case of the US H1-B visa programme.

18. Information is available for foreign trained and foreign citizen registered workers.

19. Holzmann and Koettl (2015) define portability as a mechanism to grant and transfer social security rights independently of an individual's country of residence, citizenship status or current or previous occupation.

20. Article 1 of the European Union Council Directive 90/365 limits economically inactive persons' right to reside by two important conditions: ' ... [that they] are covered by sickness insurance ... [and] ... have sufficient resources to avoid becoming a burden on the social assistance system of the host Member State during their period of residence.'

21. An alternative definition used by some researchers is based on citizenship.

\section{References}

Ackers, L., and Dwyer, P. 2004. Fixed Laws, Fluid Lives: The Citizenship Status of Postretirement Migrants in the European Union. Ageing and Society, 24, 451-475.

Adda, J., Dustmann, C., and Görlach, J. S. 2015. Migrant Wages, Human Capital Accumulation and Return Migration. Unpublished manuscript.

Adserà, A., and Ferrer, A. 2015. Immigrants and Demography: Marriage, Divorce, and Fertility. In: Chiswick, Barry R., and Miller, Paul W. (eds), Handbook of the Economics of International Migration, vol. 1A. North-Holland, pp. 315-374.

Adserà, A., Ferrer, A., Sigle-Rushton, W., and Wilson, B. 2012. Fertility Patterns of Child Migrants: Age at Migration and Ancestry in Comparative Perspective. The ANNALS of the American Academy of Political and Social Science, 643, 160189.

Akresh, I. R. 2009. Health Service Utilization among Immigrants to the United States. Population Research and Policy Review, 28, 795-815.

Andersson, G. 2004. Childbearing after Migration: Fertility Patterns of Foreign-born Women in Sweden. International Migration Review, 38, 747-774. 
Antón, J. I., and De Bustillo, R. M. 2010. Health Care Utilisation and Immigration in Spain. The European Journal of Health Economics, 11, 487-498.

Auerbach, A. J., and Oreopoulos, P. 1999. Analyzing the Fiscal Impact of US Immigration. American Economic Review, 89, 176-180.

Auerbach, A. J., and Oreopoulos, P. 2000. The Fiscal Impact of US Immigration: A Generational Accounting Perspective. In: Poterba, James (ed), Tax Policy and the Economy, vol. 14. MIT Press, Cambridge, 123-156.

Avitabile, C., Clots-Figueras, I., and Masella, P. 2014. Citizenship, Fertility, and Parental Investments. American Economic Journal: Applied Economics, 6, 35-65.

Aydemir, A. 2011. Immigrant Selection and Short-term Labor Market Outcomes by Visa Category. Journal of Population Economics, 24, 451-475.

Aydemir, A., and Borjas, G. J. 2007. Cross-country Variation in the Impact of International Migration: Canada, Mexico, and the United States. Journal of the European Economic Association, 5, 663-708.

Bach, S. 2003. International Migration of Health Workers: Labour and Social Issues. International Labour Office, Geneva.

Barone, G., and Mocetti, S. 2011. With a Little Help from Abroad: The Effect of Lowskilled Immigration on the Female Labour Supply. Labour Economics, 18, 664675.

Bettio, F., and Verashchagina, A. 2012. Long-term Care for the Elderly: Provisions and Providers in 33 European Countries. Publications Office of the European Union, Luxembourg.

Bettio, F., Simonazzi, A., and Villa, P. 2006. Change in Care Regimes and Female migration: The 'Care Drain' in the Mediterranean. Journal of European Social Policy, 16, 271-285.

Bijwaard, G. E. 2010. Immigrant Migration Dynamics Model for the Netherlands. Journal of Population Economics, 23, 1213-1247.

Blau, F. D. 1992. The Fertility of Immigrant Women: Evidence from High-fertility Source Countries. In: Borjas, George J, and Freeman, Richard B (eds), Immigration and the Workforce: Economic Consequences for the United States and Source Areas. University of Chicago Press, pp. 93-134.

Blau, F. D., Kahn, L. M., Liu, A. Y. H., and Papps, K. L. 2013. The Transmission of Women's Fertility, Human Capital, and Work Orientation across Immigrant Generations. Journal of Population Economics, 26, 405-435.

Bleakley, H., and Chin, A. 2010. Age at Arrival, English Proficiency, and Social Assimilation among US Immigrants. American Economic Journal: Applied Economics, $2,165$.

Bollini, P., Pampallona, S., Wanner, P., and Kupelnick, B. 2009. Pregnancy Outcome of Migrant Women and Integration Policy: A Systematic Review of the International Literature. Social Science \& Medicine, 68, 452-461.

Bonin, H., Patxot, C., and Souto, G. 2014. Cyclically-Neutral Generational Accounting. Fiscal Studies, 35, 117-137.

Borjas, G. J. 1989. Immigrant and Emigrant Earnings: A Longitudinal Study. Economic Inquiry, 27, 21-37.

Borjas, G. J. 1994. The Economics of Immigration. Journal of Economic Literature, 32, 1667-1717.

Borjas, G. J. 2001. Does Immigration Grease the Wheels of the Labor Market? Brookings Papers on Economic Activity, 1, 69-119. 
Borjas, G. J., and Bratsberg, B. 1996. Who Leaves? The Outmigration of the ForeignBorn. The Review of Economics and Statistics, 78, 165-76.

Bratsberg, B., Raaum, O., and Røed, K. 2010. When Minority Labor Migrants Meet the Welfare State. Journal of Labor Economics, 28, 633-676.

Bratsberg, B., Raaum, O., and Røed, K. 2014. Immigrants, Labour Market Performance and Social Insurance. The Economic Journal, 124, F644-F683.

Carballo, M. 2009a. Communicable Diseases. In: Fernandes, Ana, and Miguel, José Pereira (eds), Health and Migration in the European Union: Better Health for All in an Inclusive Society. Instituto Nacional de Saúde Doutor Ricardo Jorge, Lisbon, pp. 53-69.

Carballo, M. 2009b. Non-communicable Diseases. In: Fernandes, Ana, and Miguel, José Pereira (eds), Health and Migration in the European Union: Better Health for All in an Inclusive Society. Instituto Nacional de Saúde Doutor Ricardo Jorge, Lisbon, pp. 71-78.

Card, D. 2001. Immigrant Inflows, Native Outflows, and the Local Labor Market Impacts of Higher Immigration. Journal of Labor Economics, 19, 22-64.

CBS. 2006. Internet Database of the Centraal Bureau voor de Statistiek. CBS Statline. Statistics Netherlands. Voorburg. http://statline.cbs.nl.

Chaloff, J., and Lemaitre, G. 2009. Managing Highly-Skilled Labour Migration: A comparative Analysis of Migration Policies and Challenges in OECD Countries. Working Paper No. 79. OECD Social, Employment and Migration. OECD Publishing.

Choi, K. H. 2014. Fertility in the Context of Mexican Migration to the United States: A Case for Incorporating the Pre-migration Fertility of Immigrants. Demographic Research, 30, 703.

Chojnicki, X. 2013. The Fiscal Impact of Immigration in France: A Generational Accounting Approach. The World Economy, 36, 1065-1090.

Coleman, D. 2003. Mass Migration and Population Change. Zeitschrift für Bevölkerungswissenschaft, 28, 183-215.

Collado, M. D., Iturbe-Ormaetxe, I., and Valera, G. 2004. Quantifying the Impact of Immigration on the Spanish Welfare State. International Tax and Public Finance, 11, 335-353.

Colussi, A. 2003. Migrants' Networks: An Estimable Model of Illegal Mexican Migration. Mimeo, University of Pennsylvania, Philadelphia.

Constant, A. F., and Zimmermann, K. F. 2011. Circular and Repeat Migration: Counts of Exits and Years Away from the Host Country. Population Research and Policy Review, 30, 495-515.

Conway, K. S., and Houtenville, A. J. 2003. Out with the Old, In with the Old: A Closer Look at Younger Versus Older Elderly Migration. Social Science Quarterly, 84, 309-328.

Conway, K. S., and Houtenville, A. J. 1998. Do the Elderly 'Vote with their Feet?'. Public Choice, 97, 663-685.

Cortés, P., and Pan, J. 2014. Foreign Nurse Importation and the Supply of Native Nurses. Journal of Health Economics, 37, 164-180.

Cortés, P., and Pan, J. 2015. Relative Quality of Foreign Nurses in the United States. Journal of Human Resources, 50(4), 1009-1050.

Cortes, P., and Tessada, J. 2011. Low-skilled Immigration and the Labor Supply of Highly Skilled Women. American Economic Journal: Applied Economics, 3, 88123. 
Cots, F., Castells, X., García, O., Riu, M., Felipe, A., and Vall, O. 2007. Impact of Immigration on the Cost of Emergency Visits in Barcelona (Spain). BMC Health Services Research, 7, 9.

d'Addio, A. C., and Cavalleri, M. C. 2015. Labour Mobility and the Portability of Social Rights in the EU. CES Ifo Economic Studies, 61, 346-376.

Docquier, F., and Rapoport, H. 2012. Globalization, Brain Drain, and Development. Journal of Economic Literature, 50, 681-730.

Dubuc, S. 2012. Immigration to the UK from High-Fertility Countries: Intergenerational Adaptation and Fertility Convergence. Population and Development Review, 38, 353-368.

Duncombe, W., Robbins, M., and Wolf, D. A. 2001. Retire to Where? A Discrete Choice Model of Residential Location. International Journal of Population Geography, 7 , 281-293.

Dustmann, C. 1995. Savings Behaviour of Migrant Workers - A Life Cycle Analysis. Zeitschrift fuer Wirtschafts- und Sozialwissenschaften, 4, 511-533.

Dustmann, C. 1996. Return Migration: The European Experience. Economic Policy, 11, 213-250.

Dustmann, C. 1997. Return Migration, Uncertainty and Precautionary Savings. Journal of Development Economics, 52, 295-316.

Dustmann, C. 2000. Temporary Migration and Economic Assimilation. Swedish Economic Policy Review, 7, 213-244.

Dustmann, C. 2003. Return Migration, Wage Differentials, and the Optimal Migration Duration. European Economic Review, 47, 353-369.

Dustmann, C., and Frattini, T. 2011. The Impact of Migration on the Provision of UK Public Services. Report for the Migration Advisory Committee.

Dustmann, C., and Frattini, T. 2014. The Fiscal Effects of Immigration to the UK. The Economic Journal, 124, F593-F643.

Dustmann, C., and Görlach, J. S. 2015. Selective Out-Migration and the Estimation of Immigrants' Earnings Profiles. In: Chiswick, Barry R., and Miller, Paul W. (eds), Handbook of the Economics of International Migration, vol. 1A. North-Holland, pp. 489-533.

Dustmann, C., and Görlach, J. S. 2016. The Economics of Temporary Migrations. Journal of Economic Literature, 54(1), 98-136.

Dustmann, C., and Weiss, Y. 2007. Return Migration: Theory and Empirical Evidence from the UK. British Journal of Industrial Relations, 45, 236-256.

Dustmann, C., Frattini, T., and Halls, C. 2010a. Assessing the Fiscal Costs and Benefits of A8 Migration to the UK. Fiscal Studies, 31, 1-41.

Dustmann, C., Frattini, T., and Preston, I. 2010b. Can Immigration Constitute a Sensible Solution to Sub-national and Regional Labour Shortages? Report for the Migration Advisory Committee.

Dustmann, C., Fadlon, I., and Weiss, Y. 2011. Return Migration, Human Capital Accumulation and the Brain Drain. Journal of Development Economics, 95, 58-67.

Dwyer, P., and Papadimitriou, D. 2006. The Social Security Rights of Older International Migrants in the European Union. Journal of Ethnic and Migration Studies, 32, 1301-1319.

Dwyer, P. J. 2000. Movements to Some Purpose? An Exploration of International Retirement Migration in the European Union. Education and Ageing, 15, 353-377. 
Dyhr, L., Andersen, J. S., and Engholm, G. 2007. The Pattern of Contact with General Practice and Casualty Departments of Immigrants and Non-immigrants in Copenhagen, Denmark. Danish Medical Bulletin, 54, 226-229.

European Commission. 2014a. The 2015 Ageing Report: Underlying Assumptions and Projection Methodologies. European Economy, 8/2014.

European Commission. 2014b. Mapping and Analysing Bottleneck Vacancies in EU Labour Markets. EC Overview Report Final.

European Commission. 2015. The 2015 Ageing Report: Economic and Budgetary Projections for the 28 EU Member States (2013-2060). European Economy, 3/2015.

Facchini, G., and Lodigiani, E. 2014. Attracting Skilled Immigrants: An Overview of Recent Policy Developments in Advanced Countries. National Institute Economic Review, 229, R3-R21.

Farré, L., González, L., and Ortega, F. 2011. Immigration, Family Responsibilities and the Labor Supply of Skilled Native Women. The BE Journal of Economic Analysis \& Policy, 11, Article 34.

Fennelly, K. 2007. The 'Healthy Migrant' Effect. Minnesota Medicine, 90, 51-53.

Fernández, R., and Fogli, A. 2006. Fertility: The Role of Culture and Family Experience. Journal of the European Economic Association, 4, 552-561.

Fernández, R., and Fogli, A. 2009. Culture: An Empirical Investigation of Beliefs, Work, and Fertility. American Economic Journal: Macroeconomics, 1, 146-177.

Gale, L. R., and Heath, W. C. 2000. Elderly Internal Migration in the United States Revisited. Public Finance Review, 28, 153-170.

Garssen, J., and Nicolaas, H. 2008. Fertility of Turkish and Moroccan Women in the Netherlands: Adjustment to Native Level Within One Generation. Demographic Research, 19, 1249.

Gimeno-Feliu, L. A., Magallón-Botaya, R., Macipe-Costa, R. M., Luzón-Oliver, L., Cañada-Millan, J. L., and Lasheras-Barrio, M. 2013. Differences in the Use of Primary Care Services between Spanish National and Immigrant Patients. Journal of Immigrant and Minority Health, 15, 584-590.

Glied, S., and Sarkar, D. 2009. The Role of Professional Societies in Regulating Entry of Skilled Immigrants: The American Medical Association. In: Bhagwati, Jagdish, and Hanson, Gordon (eds), Skilled Migration: Problems, Prospects, and Policies. Oxford and New York: Oxford University Press, pp. 184-206.

Grignon, M., Owusu, Y., and Sweetman, A. 2013. The International Migration of Health Professionals. In: Chiswick, Barry R., and Miller, Paul W. (eds), International Handbook on the Economics of Migration. Edward Elgar, Cheltenham, UK, and Northampton, USA, pp. 75-97.

Gushulak, B., Pace, P., and Weekers, J. 2010. Migration and Health of Migrants. In: Koller, T (ed), Poverty and Social Exclusion in the WHO European Region: Health Systems Respond. WHO Regional Office for Europe, Copenhagen, pp. 257281.

Haas, W. H., and Serow, W. J. 2002. The Baby Boom, Amenity Retirement Migration, and Retirement Communities: Will the Golden Age of Retirement Continue? Research on Aging, 24, 150-164.

Hansen, J., and Lofstrom, M. 2003. Immigrant Assimilation and Welfare Participation: Do Immigrants Assimilate Into or Out of Welfare? Journal of Human Resources, 38, 74-98. 
Héran, F., and Pison, G. 2007. Two Children per Woman in France in 2006: Are Immigrants to Blame? Population and Societies, 432.

Holzmann, R., and Koettl, J. 2015. Portability of Pension, Health, and Other Social Benefits: Facts, Concepts, and Issues. CESifo Economic Studies, 61, 377-415.

INE. 2006. Vital Statistics 2005. Definitive data. Instituto National de Estadística. Madrid. http://ine.es/inebmenu/indice.htm.

INE. 2007. Movimiento natural de la población. Resultados provisionales 2006. Instituto National de Estadística. Madrid. http://ine.es/inebmenu/indice.htm.

Ingleby, D. 2008. New Perspectives on Migration, Ethnicity and Schizophrenia. Willy Brandt Series of Working Papers in International Migration and Ethnic Relations No. 1/08, Malmö University.

Ingleby, D. 2009. European Research on Migration and Health. Background paper for AMAC project. International Organization for Migration, Brussels.

Ingleby, D., Chimienti, M., Hatziprokopiou, P., Ormond, M., and De Freitas, C. 2005. The Role of Health in Integration. In: Fonseca, Maria Lucinda, and Malheiros, Jorge (eds), Social Integration and Mobility: Education, Housing and Health. IMISCOE Cluster B5 State of the art report. Estudos para o Planeamento Regional e Urbano no 67, Centro de Estudos Geográficos, Lisbon, pp. 89-119.

International Organization for Migration. 2012. Labour Shortages and Migration Policy. In: A. Platonova and G. Urso (eds). IOM LINET, Brussels.

ISTAT. 2007. Natalità e fecondità della popolazione residente: Caratteristiche e tendenze recenti. Anno 2004. Istituto nazionale di statistica. Roma. http://istat.it.

Jasso, G., and Rosenzweig, M. R. 1982. Estimating the Emigration Rates of Legal Immigrants Using Administrative and Survey Data: The 1971 Cohort of Immigrants to the United States. Demography, 19, 279-290.

Kahn, J. R. 1988. Immigrant Selectivity and Fertility Adaptation in the United States. Social Forces, 67, 108-128.

Kahn, J. R. 1994. Immigrant and Native Fertility during the 1980s: Adaptation and Expectations for the Future. International Migration Review, 28, 501-519.

Kennan, J., and Walker, J. R. 2011. The Effect of Expected Income on Individual Migration Decisions. Econometrica, 79, 211-251.

Kennedy, S., McDonald, J. T., and Biddle, N. 2006. The Healthy Immigrant Effect and Immigrant Selection: Evidence from Four Countries. Social and Economic Dimensions of an Aging Population Research Papers No. 164. McMaster University, Hamilton.

Kerr, W. R., and Lincoln, W. F. 2010. The Supply Side of Innovation: H-1B Visa Reforms and US Ethnic Invention. Journal of Labor Economics, 28, 473-508.

Kirdar, M. G. 2012. Estimating the Impact of Immigrants on the Host Country Social Security System when Return Migration is an Endogenous Choice. International Economic Review, 53, 453-486.

Kugler, A. D., and Sauer, R. M. 2005. Doctors without Borders? Relicensing Requirements and Negative Selection in the Market for Physicians. Journal of Labor Economics, 23, 437-465.

Kytir, J. 2006. Demographische Strukturen und Trends 2005. 9, 777-790.

Leclere, F. B., Jensen, L., and Biddlecom, A. E. 1994. Health Care Utilization, Family Context, and Adaptation among Immigrants to the United States. Journal of Health and Social Behavior, 35, 370-384. 
Legido-Quigley, H., and La Parra, D. 2007. The Health Care Needs of UK Pensioners Living in Spain: An Agenda for Research. Eurohealth, 13, 14-17.

Lessem, R. 2013. Mexico-US immigration: Effects of Wages and Border Enforcement. Working paper. Carnegie-Mellon University, Tepper School of Business, Pittsburgh.

Litwak, E., and Longino, C. F. 1987. Migration Patterns among the Elderly: A Developmental Perspective. The Gerontologist, 27, 266-272.

Lubotsky, D. 2007. Chutes or Ladders? A Longitudinal Analysis of Immigrant Earnings. Journal of Political Economy, 115, 820-867.

MAC. 2008. A Review of Labour Shortages, Skills Shortages and Skill Gaps. Migration Advisory Committee, London.

MAC. 2010. Skilled, Shortage, Sensible. Review of Methodology. Migration Advisory Committee, London.

Martin, P., and Ruhs, M. 2011. Labor Shortages and US Immigration Reform: Promises and Perils of an Independent Commission. International Migration Review, 45, 174-187.

Mayer, J., and Riphahn, R. T. 2000. Fertility Assimilation of Immigrants: Evidence from Count Data Models. Journal of Population Economics, 13, 241-261.

Mayr, K. 2005. The Fiscal Impact of Immigrants in Austria: A Generational Accounting Analysis. Empirica, 32, 181-216.

McCormack, V. A., Perry, N., Vinnicombe, S. J., and dos Santos Silva, I. 2008. Ethnic Variations in Mammographic Density: A British Multiethnic Longitudinal Study. American Journal of Epidemiology, 168, 412-421.

McHale, J., and Rogers, K. 2009. Selecting Economic Immigrants: A Statistical Approach. Working Paper No. 0145. National University of Ireland, Galway.

Mladovsky, P. 2007. Migration and Health in the EU. Research note. European Commission, Brussels.

Morris, S., Sutton, M., and Gravelle, H. 2005. Inequity and Inequality in the Use of Health Care in England: An Empirical Investigation. Social Science \& Medicine, 60, 1251-1266.

Moser, K., Patnick, J., and Beral, V. 2009. Inequalities in Reported Use of Breast and Cervical Screening in Great Britain: Analysis of Cross Sectional Survey Data. British Medical Journal, 338, 1480-1484.

Nekby, L. 2006. The Emigration of Immigrants, Return vs Onward Migration: Evidence from Sweden. Journal of Population Economics, 19, 197-226.

Nielsen, S. S., Krasnik, A., and Rosano, A. 2009. Registry Data for Cross-country Comparisons of Migrants' Healthcare Utilization in the EU: A Survey Study of Availability and Content. BMC Health Services Research, 9, 210.

OECD. 2014. OECD Factbook 2014: Economic, Environmental and Social Statistics. OECD Publishing. http://dx.doi.org/10.1787/factbook-2014-en.

ONS. 2006. Birth Statistics. Review of the Registrar General on Births and Patterns of Family Building England and Wales, 2005. Series FM1. No. 34. Office of National Statistics. London.

ONS. 2007. Fertility Rate is Highest for 26 Years. News release, 7 June 2007. Office of National Statistics. London.

Parrado, E. A., and Morgan, S. P. 2008. Intergenerational Fertility among Hispanic Women: New Evidence of Immigrant Assimilation. Demography, 45, 651-671. 
Peterson, B. D., Pandya, S. S., and Leblang, D. 2014. Doctors with Borders: Occupational Licensing as an Implicit Barrier to High Skill Migration. Public Choice, 160, 45-63.

Preston, I. 2014. The Effect of Immigration on Public Finances. The Economic Journal, 124, F569-F592.

Price, C. L., Szczepura, A. K., Gumber, A. K., and Patnick, J. 2010. Comparison of Breast and Bowel Cancer Screening Uptake Patterns in a Common Cohort of South Asian Women in England. BMC Health Services Research, 10.

Prioux, F. 2005. Recent Demographic Developments in France. Population-E, 60, 371414.

Razin, A., and Sadka, E. 1999. Migration and Pension with International Capital Mobility. Journal of Public Economics, 74, 141-150.

Razin, A., and Sadka, E. 2000. Unskilled Migration: A Burden or a Boon for the Welfare State? The Scandinavian Journal of Economics, 102, 463-479.

Reagan, P. B., and Olsen, R. J. 2000. You Can Go Home Again: Evidence from Longitudinal Data. Demography, 37, 339-350.

Rechel, B., Mladovsky, P., Devillé, W., Rijks, B., Petrova-Benedict, R., and McKee, M. 2011. Migration and Health in the European Union: An Introduction. In: Rechel, Bernd, Mladovsky, Philipa, Devillé, Walter, Rijks, Barbara, Petrova-Benedict, Roumyana, and McKee, Martin (eds), Migration and Health in the European Union. Open University Press McGraw-Hill Education. UK.

Reijneveld, S. A. 1998. Reported Health, Lifestyles, and Use of Health Care of First Generation Immigrants in The Netherlands: Do Socioeconomic Factors Explain Their Adverse Position? Journal of Epidemiology and Community Health, 52, 298304.

Riphahn, R. T. 2004. Immigrant Participation in Social Assistance Programs: Evidence from German Guestworkers. Applied Economics Quarterly, 50, 329-362.

Roig Vila, M., and Martín, T. Castro. 2007. Childbearing Patterns of Foreign Women in a New Immigration Country: The Case of Spain. Population-E, 62, 351380.

Rowthorn, R. 2008. The Fiscal Impact of Immigration on the Advanced Economies. Oxford Review of Economic Policy, 24, 560-580.

Ruist, J. 2014. Free Immigration and Welfare Access: The Swedish Experience. Fiscal Studies, 35, 19-39.

Sanderson, W. C., and Scherbov, S. 2010. Remeasuring Aging. Science, 329, 12871288.

Schoorl, J. 1995. Fertility Trends of Immigrant Populations. Proceedings of the Symposium, NIAS, Wasenaar, 27-29 September 1990. Report No. 44. The Hague: NIDI.

Schumacher, E. J. 2011. Foreign-born Nurses in the US Labor Market. Health Economics, 20, 362-378.

SFSO. 2006. Statistique du mouvement naturel de la population. Résultats définitifs 2005. Swiss Federal Statistical Office. Neuchâtel. http://bfs.admin.ch/.

Smaje, C., and Le Grand, J. 1997. Ethnicity, Equity and the Use of Health Services in the British NHS. Social Science \& Medicine, 45, 485-496.

Sobotka, T. 2008. The Rising Importance of Migrants for Childbearing in Europe. Demographic Research, 19, 225-248. 
Solé-Auró, A., Guillén, M., and Crimmins, E. M. 2012. Health Care Usage among Immigrants and Native-born Elderly Populations in Eleven European Countries: Results from SHARE. The European Journal of Health Economics, 13, 741-754.

Stallmann, J. I., Deller, S. C., and Shields, M. 1999. The Economic and Fiscal Impact of Aging Retirees on a Small Rural Region. The Gerontologist, 39, 599610.

Statistics Denmark. 2004. Befolkningens bevaegelser 2003. (Vital statistics 2003). Danmarks Statistik. Copenhagen.

Statistics Sweden. 2006. Tabeller över Sveriges befolkning. Statistics Sweden. Statistiska centralbyrán Stockholm.

Statistisches Bundesamt. 2006. Statistisches Jahrbuch 2006. Statistisches Bundesamt. Wiesbaden. https://destatis.de/DE/Startseite.html.

Stephen, E. H., and Bean, F. D. 1992. Assimilation, Disruption and the Fertility of Mexican-Origin Women in the United States. International Migration Review, 26, 67-88.

Storesletten, K. 2000. Sustaining Fiscal Policy through Immigration. Journal of Political Economy, 108, 300-323.

Storesletten, K. 2003. Fiscal Implications of Immigration: A Net Present Value Calculation. The Scandinavian Journal of Economics, 105, 487-506.

The Economist. 2013, June 15th. Erasmus Generation: To Overcome Its Skills Shortage, Germany Needs to Remodel Its Society. http://economist.com/news/specialreport/21579148-overcome-its-skills-shortage-germany-needs-remodel-itssociety-erasmus-generation.

Thom, K. 2010. Repeated Circular Migration: Theory and Evidence from Undocumented Migrants. Mimeo, New York University.

Toulemon, L. 2004. Fertility among Immigrant Women: New Data, a New Approach. Population and Societies, 1-4.

Toulemon, L., Pailhé, A., and Rossier, C. 2008. France: High and Stable Fertility. Demographic Research, 19, 503-556.

Tribalat, M. 2005. Fécondité des immigrées et apport démographique de l'immigration étrangère. vol. 2. UDEP / IEDUB, Bordeaux.

Uiters, E., Deville, W. L. J. M., Foets, M., and Groenewegen, P. P. 2006. Use of Health Care services by Ethnic Minorities in The Netherlands: Do Patterns Differ? The European Journal of Public Health, 16, 388-393.

Van Hooren, F. J. 2012. Varieties of Migrant Care Work: Comparing Patterns of Migrant Labour in Social Care. Journal of European Social Policy, 22, 133-147.

VAZG. 2007. Tables on Births in Flanders Provided by the Flemish Healthcare Agency. Vlaams Agentschap Zorg en Gezondheit. http://zorg-en-gezondheid.be/topPage .aspx?id=684.

Wadsworth, J. 2013. Mustn't Grumble: Immigration, Health and Health Service Use in the UK and Germany. Fiscal Studies, 34, 55-82.

Webb, R., Richardson, J., Esmail, A., and Pickles, A. 2004. Uptake for Cervical Screening by Ethnicity and Place-of-birth: A Population-based Cross-sectional Study. Journal of Public Health, 26, 293-296.

WHO. 2010. How Health Systems Can Address Health Inequities Linked to Migration and Ethnicity. World Health Organization Regional Office for Europe, Copenhagen. 
WHO. 2014. Migration of Health Workers: WHO Code of Practice and the Global Economic Crisis. World Health Organization Report, Geneva.

Winkelmann, R. 2002. Work and Health in Switzerland: Immigrants and Natives. Working Paper No. 0203, Socioeconomic Institute-University of Zurich.

Wolff, H., Epiney, M., Lourenco, A. P., Costanza, M. C., Delieutraz-Marchand, J., Andreoli, N., Dubuisson, J. B., Gaspoz, J. M., and Irion, O. 2008. Undocumented migrants Lack Access to Pregnancy Care and Prevention. BMC Public Health, 8. 